Dorota DOMALEWSKA

Akademia Sztuki Wojennej ${ }^{1}$

Wydzial Bezpieczeństwa Narodowego

d.domalewska@akademia.mil.pl

ORCID 0000-0002-1788-1591

Ilona URYCH

Akademia Sztuki Wojennej ${ }^{2}$

Wydzial Bezpieczeństwa Narodowego

i.urych@akademia.mil.pl

ORCID 0000-0003-4868-9460

https://doi.org/10.34739/dsd.2020.01.12

\title{
AKSJOLOGICZNE I ANTROPOLOGICZNE UWARUNKOWANIA TOŻSAMOŚCI NARODOWEJ MLODYCH POLAKÓW W ŚWIETLE BADAŃ WLASNYCH. IMPLIKACJE DLA BEZPIECZEŃSTWA NARODOWEGO ${ }^{3}$
}

\begin{abstract}
ABSTRAKT: Kształtowanie patriotyzmu i tożsamości narodowej ma kluczowe znaczenie dla przetrwania narodu. Ważnym obszarem budowania i wzmacniania patriotyzmu jest sport, który stanowi spoiwo tożsamości narodowej oraz wzmacnia takie wartości jak solidarność i tolerancja, co buduje aktywne postawy obywatelskie w społeczeństwie. Niniejszy artykuł ma w swym zasadniczym celu omówienie istoty patriotyzmu, tożsamości narodowej i tolerancji, które stanowią wymiar postawy jednostki wobec innych narodów oraz sportowego patriotyzmu, który stanowi istotne spoiwo tożsamości narodowej. Badanie przeprowadzono przy użyciu metody sondażu diagnostycznego. Analiza uzyskanych danych wskazuje na bardzo silne poczucie patriotyzmu, tożsamości narodowej i patriotyzmu sportowego wśród respondentów $(\mathrm{N}=508)$. Skala patriotyczna znacząco wpływała na wyniki skali tożsamości narodowej i sportowego patriotyzmu, nie różnicowała natomiast postawy tolerancji. Z kolei skala tolerancji istotnie korelowała ze skalą patriotyzmu, sportowego patriotyzmu, tożsamości narodowej. Jak wskazuje Strategia Bezpieczeństwa Narodowego Rzeczypospolitej Polskiej, ochrona i umacnianie tożsamości narodowej stanowi ważne zadanie państwa. Cele te można osiągnąć poprzez pielęgnowanie kultury narodowej, ochronę dziedzictwa kulturowego, aktywizację kapitału społecznego oraz wzmacnianie postaw patriotycznych.
\end{abstract}

SŁOWA KLUCZOWE: tożsamość narodowa, patriotyzm, tolerancja, integracja, sport, wartości, klasy wojskowe, bezpieczeństwo narodowe

\footnotetext{
1 The War Studies University, Poland.

2 The War Studies University, Poland.

${ }^{3}$ Badanie sfinansowano ze środków Ministerstwa Obrony Narodowej (umowa nr GB/4/2018/208/2018/DA).
} 


\title{
AXIOLOGICAL AND ANTHROPOLOGICAL ASPECT OF NATIONAL IDENTITY: A QUANTITATIVE STUDY WITH IMPLICATIONS FOR NATIONAL SECURITY
}

\begin{abstract}
Shaping patriotism and national identity is crucial precondition for the survival of the nation. Sport helps to build and reinforce patriotism, binds national identity and strengthens values such as solidarity and tolerance. The main purpose of this article is to analyze the values of patriotism, national identity, tolerance, and sports patriotism, which is an important binder of national identity. The study was carried out using a diagnostic survey method. The analysis of the findings indicates a very strong sense of patriotism, national identity and sports patriotism among the respondents $(\mathrm{N}=508)$. The patriotic scale significantly influenced the results of the scale of national identity and sport patriotism, but did not differentiate the attitude of tolerance. The scale of tolerance significantly correlated with the scale of patriotism, sports patriotism and national identity. As indicated by the National Security Strategy of the Republic of Poland, preservation and reinforcement of national identity is an important task of the state. These goals can be achieved by cultivating national culture, protecting cultural heritage, activating social capital and strengthening patriotic attitudes.
\end{abstract}

KEYWORDS: national identity, patriotism, tolerance, integration, sport, values, military classes, national security

\section{WPROWADZENIE}

Kształtowanie patriotyzmu i tożsamości narodowej ma kluczowe znaczenie dla przetrwania narodu, tak jak suwerenność jest warunkiem przetrwania państwa. Społeczeństwa, które odczuwają zagrożenie bezpieczeństwa społecznego, wykształcają szereg mechanizmów obronnych mających na celu wzmocnienie tożsamości społecznej, np. wzmocnienie społecznej kohezji i odrębności za pomocą środków kulturowych oraz zapewnienie sobie przetrwania ${ }^{4}$. Społeczeństwo zatem broni swoją tożsamość przed zagrożeniami poprzez odwołanie się do swojej kultury, religii i historii. W ten sposób tworzy formę narodowego nacjonalizmu, którego celem jest wzmocnienie tożsamości danej grupy 5 .

Warto przy tym wskazać, że ważnym obszarem budowania i wzmacniania tożsamości narodowej jest sport ${ }^{6}$. Pomaga on zacierać różnice rasowe i narodowościowe, a zarazem kultywować przynależność narodową ${ }^{7}$. Wzmacnia również takie wartości jak solidarność i tolerancja, co buduje aktywne postawy obywatelskie w społeczeństwie. Sport staje się spoiwem tożsamości narodowej, wzmacniającym poczucie odrębności i niezależności, budującym dumę i prestiż $\mathrm{kraju}^{8}$ oraz promującym nacjonalizm ${ }^{9}$. Dla Buttlerwortha ${ }^{10}$

\footnotetext{
${ }^{4}$ Vide: O. Wæver, The Changing Agenda of Societal Security, [w:] Globalization and Environmental Challenges, Reconceptualizing Security in the 21st Century, red. H.G. et al. Brauch, Berlin 2008.

${ }^{5}$ A. Saleh, Broadening the Concept of Security: Identity and Societal Security, „Geopolitics Quarterly 6”, no. 4 (2010): 228-41; R. Ivancik, V. Jurcak, P. Necas, On Some Contemporary Global Security Risks and Challenges, „Security and Defence Quarterly 4”, no. 3/2014, s. 34-49.

${ }^{6}$ Vide: A. Bairner, Sport, Nationalism, and Globalization: European and North American Perspectives,, New York 2001.

${ }^{7}$ Ł. Panfil, T. Seweryniak, Wybrane czynniki umiędzynaradawiania kadr organizacji sportowych, Wrocław 2009, s. 25.

${ }^{8}$ P. Cedro, Spoleczna Rola Sportu, „,Rozprawy Społeczne 7”, no. 2/2013, s. 79-80.
} 
rozgrywki sportowe są forum, na którym rozgrywa się zarówno gorliwy nacjonalizm, jak i pokojowa rywalizacja. Bairner ${ }^{11}$ natomiast thumaczy współwystępowanie tych wartości ich afektywnym nacechowaniem twierdząc, że sport i nacjonalizm to dwie najbardziej emocjonujące postawy we współczesnym świecie.

Niniejszy artykuł ma w swym zasadniczym celu omówienie istoty patriotyzmu, tożsamości narodowej i tolerancji, które stanowią wymiar postawy jednostki wobec innych narodów ${ }^{12}$, oraz sportowego patriotyzmu, który stanowi istotne spoiwo tożsamości narodowej. Analiza zależności między powyższymi wartościami oraz wpisanie ich w szerszy kontekst społeczny skutkowały postawieniem pytania: $\mathrm{w}$ jakim zakresie sport koreluje z postawami patriotycznymi i tolerancją? W ujęciu metodologicznym uniknięto podziału na „dobry” i ,zły” nacjonalizm, ale przyjęto za Billingsem et al. ${ }^{13}$ podział na patriotyzm i tożsamość narodową. Przyjęto hipotezę, że tożsamość narodowa badanych charakteryzuje się poczuciem konieczności czczenia naszej narodowej historii i dziedzictwa, patriotyzm związany jest z miłością do ojczyzny, sportowy patriotyzm łączy się z kibicowaniem Polsce na międzynarodowych zawodach sportowych, tolerancja zaś jest związana $\mathrm{z}$ akceptacją na osiedlanie się w Polsce osób bliskich nam kulturowo, np. z Ukrainy $\left(\mathrm{H}_{1}\right)$. Istnieje znaczna (powyżej 0,5) współzależność między tożsamością narodową, patriotyzmem, tolerancją i sportowym patriotyzmem badanej młodzieży $\left(\mathrm{H}_{2}\right)$. Założono, że wiek, płeć i miejsce zamieszkania wpływają znacząco na poczucie tożsamości narodowej, tolerancji i sportowego patriotyzmu $\left(\mathrm{H}_{3}\right)$.

W celu rozwiązania przedstawionej problematyki badawczej i weryfikacji założonych hipotez przeprowadzono badanie ilościowe przy użyciu metody sondażu diagnostycznego i techniki ankiety oraz narzędzia w postaci kwestionariusza ankiety, który składała się ze skali patriotyzmu, tożsamości narodowej, sportowego patriotyzmu (przygotowanej w oparciu o ankietę opracowaną przez Billingsa et $a l .{ }^{14}$ ) oraz tolerancji. Badaniem objęto 508 respondentów. Artykuł prezentuje również teoretyczny wymiar badań i analizuje cztery kluczowe pojęcia: tożsamość narodowa, patriotyzm, tolerancja i sportowy patriotyzm.

\footnotetext{
9 A.C. Billings, K.A. Brown, N.A. Brown, 5,535 Hours of Impact: Effects of Olympic Media on Nationalism Attitudes, „Journal of Broadcasting\&Electronic Media 57”, no. 4/2013, s. 579-95; M. L. Butterworth, The Politics of the Pitch: Claiming and Contesting Democracy Through the Iraqi National Soccer Team, „Communication and Critical/Cultural Studies 4”, no. 2 (June 2007): 184-203.

${ }^{10}$ M.L. Butterworth, The Politics of the Pitch: Claiming and Contesting Democracy Through the Iraqi National Soccer Team, „Communication and Critical/Cultural Studies 4”, no. 2/2007, s. 187.

${ }^{11}$ A. Bairner, Sport, Nationalism, and Globalization...

${ }^{12}$ Vide: A. Sułek, Psychospołeczne Uwarunkowania Patriotyzmu i Nacjonalizmu, Kraków 2012.

13 A.C. Billings, K.A. Brown, N.A. Brown, 5,535 Hours of Impact: Effects of Olympic Media on Nationalism Attitudes, „Journal of Broadcasting and Electronic Media 57”, no. 4/2013, s. 579-95.

${ }^{14}$ Ibidem.
} 


\section{TOŻSAMOŚĆ NARODOWA}

Znaczenie tożsamości narodowej w zapewnieniu bezpieczeństwa państwa jest

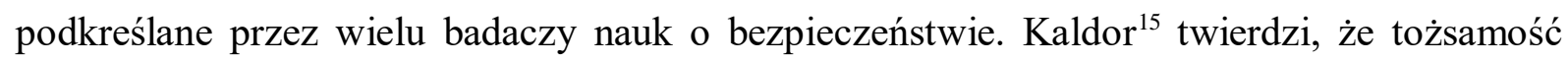
stała się zarzewiem nowego rodzaju konfliktu, wojny o tożsamość, której często towarzyszą czystki etniczne, nadmierne utrwalenie tożsamości, wzrost przestępczości w trakcie trwania konfliktu oraz wojna domowa. Z kolei Waever ${ }^{16}$ twierdzi, że społeczeństwa, które odczuwają zagrożenie podejmują szereg mechanizmów obronnych mających na celu wzmocnienie ich tożsamości, np. wzmocnienie społecznej kohezji i odrębności za pomocą środków kulturowych oraz zapewnienie sobie przetrwania. Buzan et al. ${ }^{17}$ wskazuje na religię oraz na nacjonalizm jako na główne przyczyny mobilizacji grupy społecznej, wzmocnienia dychotomii my - oni, intensyfikacji strachu i nienawiści przeciwko grupie obcej.

Geneza badań nad tożsamością sięga początków XX wieku. Pojęciem „tożsamości” posłużył się w roku 1905 Boris Sidis ${ }^{18}$, chociaż w literaturze przedmiotu spotyka się także twierdzenie, że pojęcie tożsamości wprowadził do refleksji psychologicznej na początku XX wieku Viktor Tausk ${ }^{19}$. Upowszechnienie badań dotyczących tożsamości jest natomiast zasługą Erika H. Eriksona ${ }^{20}$. Istotny wkład miały także prace takich uczonych jak Anselm L. Strauss ${ }^{21}$, Peter L. Berger ${ }^{22}$ czy Erving Goffman ${ }^{23}$.

W naukach społecznych kategorię tożsamości zaczęto analizować w odniesieniu do społecznego funkcjonowania jednostki oraz stabilnych autocharakterystyk jednostki, które są nabywane przez odniesienie do społecznego funkcjonowania, a widziane integralnie z przynależnością do określonej grupy i pełnionej roli. Dlatego też znaczną popularność zyskała teoria tożsamości społecznej (ang. Social Identity Theory), która wyjaśnia napięcie między przynależnością grupową a postrzeganiem samego siebie przez jednostkę, ocenę swojej grupy oraz tych, którzy widziani są jako obcy. Istotną kwestią jest tu także analiza faworyzmu dla własnej grupy i dyskryminacji dla obcych (uprzedzenia i stereotypy), ludzka skłonność do łączenia się w grupy dla uzyskania większego poczucia siebie samego (kim się jest). Koncepcję i rozwój teorii tożsamości społecznej należy łączyć z dwoma psychologami społecznymi: Henri Tajfelem i Johnem Charlesa'em Turnerem ${ }^{24}$.

\footnotetext{
${ }^{15}$ M. Kaldor, In Defence of New Wars, „Stability: International Journal of Security and Development 2”, no. $1 / 2013$, s. 4.

${ }^{16}$ Vide: O. Wæver, The Changing Agenda of Societal Security.

${ }^{17}$ Vide: B. Buzan, O. Wæver, J. de. Wilde, Security: A New Framework for Analysis, Colorado 1998.

${ }^{18}$ Vide: B. Sidis, Multiple Personality: An Experimental Investigation into the Nature of Human Individuality, New York 1905.

${ }^{19}$ Vide: V. Tausk, P. Roazen, Sexuality, War, and Schizophrenia: Collected Psychoanalytic Papers, New Jersey 2017.

${ }^{20}$ Vide: E.H. Erikson, Identity: Youth and Crisis, New York 1994.

${ }^{21}$ Vide: A.L. Strauss, Mirrors and Masks: The Search for Identity, Glenoce 1959.

${ }^{22}$ Vide: P.L. Berger, T. Luckmann, The Social Construction of Reality: A Treatise in the Sociology of Knowledge, New York 1966.

${ }^{23}$ Vide: E. Goffman, Czlowiek w teatrze życia codziennego, Warszawa 2008.

${ }^{24}$ Vide: H. Tajeel, J.C. Turner, An Integrative Theory of Intergroup Conflict, „The Social Psychology of Intergroup Relations 33", no. 47 (1979).
} 
Okazało się również, że pojęcie tożsamości jest istotne dla określenia i opisu jednostek i wspólnot. Analizie poddawano uznanie samej grupy i jej poglądów, które nie tylko określają i konsolidują daną wspólnotę, lecz także wskazują jej wyróżniki i miejsce w społeczeństwie, są czytelnym wyróżnikiem, przyciągającym lub odpychającym. Do popularyzacji takiego ujęcia tożsamości przyczyniły się badania na temat tożsamości rasowej, etnicznej, narodowej, klasowej, seksualnej, religijnej i innych. Analiza wyników badań dotyczących tożsamości ukierunkowała postrzeganie jej w kategoriach procesu i wyboru, a nie narzucenia ${ }^{25}$.

Tożsamość może być zatem rozpatrywana dwuaspektowo: jako tożsamość osobista (indywidualna) i tożsamość zbiorowa (społeczna). Tożsamość indywidualna rozumiana jest jako subiektywna świadomość siebie, poczucie odrębności i unikalności. Kształtuje się ona na podstawie osobistego doświadczenia, interakcji ze środowiskiem zewnętrznym (kiedy jednostka organizuje i konstruuje bądź rekonstruuje wiedzę o sobie) oraz w oparciu o cechy osobowości, a stanowi o poczuciu spójności i stabilności.

Tożsamość społeczna jednostki jest związana z poczuciem pełnienia określonych ról, zajmowaniem przez nią określonego miejsca w społeczeństwie ${ }^{26}$. Oznacza identyfikację jednostki z różnymi grupami społecznymi, które stanowią o jej autodefinicji, jest świadomościowym odbiciem społecznych relacji zobowiązań, zależności, współpracy oraz wspólnych interesów ${ }^{27}$. Tożsamość zbiorowa wskazuje więc na ukształtowanie jednostki podkreślając jej przynależność do grupy i uwydatniając jej cechy wspólne z grupą, które uwidaczniają się we wspólnych dążeniach, wartościach i celach. Zgodnie z teorią tożsamości społecznej Henri Tajfela i Johna Turnera jednostka posiada kilka tożsamości społecznych, które rodzą się w wyniku przynależności do jednej lub kilku grup społecznych, kiedy przynależność do tych grup stanowi pewną wartość i jest naładowana emocjonalnie ${ }^{28}$. Ludzie postrzegają siebie i innych przez pryzmat przynależności do różnych grup społecznych, co pozwala im zrozumieć złożoną rzeczywistość. Podział na grupy społeczne dokonywany jest nie tylko na podstawie porównania $\mathrm{z}$ innymi grupami, lecz także $\mathrm{w}$ wyniku symplifikacji i stereotypizacji. Ponadto przynależność do różnych grup pozytywnie oddziałuje na poczucie własnej wartości jej członków. Porównywanie grup natomiast prowadzi z jednej strony do faworyzowania grupy własnej, a z drugiej strony jest związane ze współzawodnictwem, stereotypizacją, a nawet dyskryminacją członków grupy obcej ${ }^{29}$, ponieważ rzekome różnice

\footnotetext{
${ }^{25}$ D.-C. Martin, The Choices of Identity, „Social Identities 1”, no. 1/1995, s. 5-20.

${ }^{26}$ W. Knapik, Tradycje jako element tożsamości kulturowej wiejskich społeczności lokalnych [w:] Tradycja dla współczesności. Ciagłość i zmiana, t. 3, red. J. Styka, M. Dziekanowska, Lublin 2011, s. 251.

27 M. Golka, Imiona wielokulturowości, Warszawa 2010, s. 355-356; A. Mitręga, M. Kozub, The Influence of Strategic Culture on Shaping Security Policy, ,Security and Defence Quarterly 27”, no. 5/2019, s. 44-56.

${ }^{28}$ Vide: H.Tajfel, The Structure of Our Views about Society, [w:] Introducing Social Psychology, red. H. Tajfel, C. Fraser, Harmondsworth 1978.

${ }^{29}$ K. Błeszyńska, Tożsamość Polaków w dobie globalnej, [w:] Edukacja wobec ładu globalnego, red. T. Lewowicki, Warszawa 2002, s. 256.
} 
między grupami są często wyolbrzymiane, a pozytywny wizerunek własnej grupy przekłada się na wyższe poczucie własnej wartości ${ }^{30}$.

Tożsamość zbiorowa silnie nawiązuje do tożsamości narodowej, ponieważ naród to jedna z kategorii społecznych. Max Weber postrzegał naród jako wspólnotę, którą łączy pochodzenie, religię, kulturę, język, historię. Antonina Kłoskowska i Florian Znaniecki również definiują naród jako wspólnotę uczestniczącą w pewnych wartościach kulturowych. Jak podkreśla Kłoskowska ${ }^{31}$, rola kultury narodowej miała niebagatelne znaczenie w kształtowaniu się i funkcjonowaniu narodu, szczególnie w przypadku Polski, która utraciła swoją państwowość na 123 lata. Z kolei Talcott Parsons ${ }^{32}$, twórca funkcjonalnostrukturalistycznej teorii systemów społecznych, definiuje naród jako wspólnotę ludzi, którzy są obywatelami jednego państwa i którzy mieszkają w granicach wspólnego terytorium. Przytoczone powyżej definicje dowodzą, że termin „,naród” może być definiowany na wiele sposobów, a zatem pojęcie tożsamości narodowej również może być rozumiane wielorako.

Przyjmując perspektywę antropologiczną, tożsamość narodowa oznacza przynależność do grupy etnicznej, z perspektywy politologii natomiast tożsamość narodowa łączy się $\mathrm{z}$ byciem obywatelem kraju oraz przyzwoleniem na to, by działania jednostki były kierowane poczuciem lojalności, odpowiedzialności i solidarności względem kraju i innych obywateli ${ }^{33}$. Stanisław Gajda ${ }^{34}$ określa tożsamość jako ,względnie trwałą/zmienną w czasie i sytuacyjnie identyfikację podmiotu z określonym systemem znaczeń (idei, przekonań, wartości, norm itp.), opierającym się na przeżywaniu i zinterioryzowaniu elementów przeszłości i wyobrażeń przyszłości”. Z kolei Samuel Huntington ${ }^{35}$ wyróżnia następujące komponenty tożsamości narodowej:

- religia i wiara będące wartościami ułatwiającymi kulturową partycypację, solidarność społeczną oraz rozwiązywanie konfliktów,

- dziedzictwo narodowe, tj. historia, która tworzy odrębność narodu,

- kulturowa jednolitość w odróżnieniu od kulturowego zróżnicowania,

- etnocentryzm.

Wskazać również należy, że tożsamość narodowa nie jest pojęciem stałym i jednolitym, a badacze wręcz podkreślają, że tożsamość narodowa kształtuje się dopiero w momencie poczucia zagrożenia, a zatem można wysunąć konkluzję, że to identyfikacja zagrożenia

\footnotetext{
${ }^{30}$ D. Domalewska, Immigration, Stereotypes, and Social Security: The Portrayal of Migrant Groups in Public Discourse, „Security and Defence Quarterly 4”, no. 13/2016, s. 15-31.

${ }^{31}$ Vide: A. Kłoskowska, Kultury narodowe u korzeni, Warszawa 1996.

${ }^{32}$ Vide: T. Parsons, Sociological Theory and Modern Society, New York 1967.

33 K. Błeszyńska, Tożsamość Polaków w dobie globalnej..., s. 257.

${ }^{34}$ Vide: S. Gajda, Tożsamość a język, [w:] Człowiek wobec wyzwań współczesności. wpadek wartości czy walka o wartość? , red. J. Mazur, A. Małyska, K. Sobstyl, Lublin 2007

35 Vide: S.P. Huntington, The Clash of Civilizations and the Remaking of World Order, New York 2011.
} 
tworzy rdzeń tożsamości społecznej ${ }^{36}$, która jest warunkowana m.in. przez zależności społeczno-kulturowe ${ }^{37}$.

\section{PATRiotyzm}

Tożsamość narodowa przejawia się w patriotyzmie, który można zdefiniować jako „wszelkie umiłowanie ojczyzny jako miejsca swojego pochodzenia i/lub zamieszkania” 38 . Podobnie ujmując można zdefiniować patriotyzm jako „cnotę moralną miłości do ojczyzny ziemi ojczystej, zamieszkujących ją ludzi, jej ładu politycznego, zinstytucjonalizowanego w państwie i personifikowanego przez suwerena oraz do jej dziedzictwa kulturalnego i ładu moralnego" oraz wskazać, że „na poziomie elementarnym i powszechnie zrozumiałym patriotyzm to pewna dyspozycja psychiczna, prymarnie emocjonalna (obejmująca uczucia, takie jak przywiązanie, nostalgia i tęsknota), będąca miłością do kraju ojców (patres)"39. Można zatem stwierdzić, że patriotyzm to również „relacja człowieka do społeczności i systemu wspólnotowych wartości o charakterze afirmatywnym" ${ }^{40}$. Dlatego też to właśnie patriotyzm - jak dowodzi Jerzy Szacki - jest warunkiem koniecznym zarówno powstania, jak i ponadpokoleniowego trwania grupy społecznej. „Nie ma grupy społecznej, której członkowie nie czuliby się do siebie wzajemnie podobni, nie mieliby poczucia związku z określonym miejscem na Ziemi, którym brakowałoby co najmniej odświętnej solidarności i zdolności mobilizowania się do wspólnego działania w sytuacjach zewnętrznego zagrożenia. Dotyczy to w szczególności, acz nie tylko, grup etnicznych i narodów, a więc takich grup, do których większość jednostek wchodzi przez sam fakt swego urodzenia z takich, a nie innych rodziców" ${ }^{\text {41. }}$.

Patriotyzm charakteryzuje się silną emocjonalną więzią, poczuciem przynależności, lojalności i identyfikacji, a także poczuciem solidarności z innymi członkami grupy. „Współuczestnictwo w wartościach moralnych tworzy zażyłość, powiększa poczucie sensowności istnienia, wyzwala wyższe motywacje, sprawia, że jednostki stają się zdolne do służby i ofiarności" ${ }^{42}$.

\footnotetext{
${ }^{36}$ A. Saleh, Broadening the Concept of Security...

37 M. Górnikiewicz, T. Szczurek, Determinanty ksztaltowania bezpieczeństwa wewnętrznego, [w:] Prognozowanie międzynarodowych stosunków wojskowych na podstawie uwarunkowań spolecznokulturowych, red. E. Ślachcińska, Poznań 2017, s. 103-113; K. Świerszcz, Integralne wychowanie na rzecz integralnego bezpieczeństwa - jako naglace wyzwanie wspótczesnych czasów, [w:] Obronność państwa. Uwarunkowania oraz organizacja bezpieczeństwa i obronności, red. Z. Trejnis, M. Marciniak Toruń 2016, s. 158-93; M. Gawlik-Kobylińska, Ethics and Innovations in Military Environments, „Zeszyty Naukowe Politechniki Śląskiej 128" 2018, s. 89-97.

${ }^{38}$ R. Kaczorowski, Wielka Encyklopedia PWN, Warszawa 2004, s. 380.

39 J. Bartyzel, B. Szlachta, A. Wielomski, Encyklopedia polityczna, t. 1, Radom 2007, s. 294.

40 P. Burgoński, Polski patriotyzm w dobie komunizmu. Koncepcja patriotyzmu w nauczaniu księdza Jerzego Popietuszki, ,Warszawskie Studia Teologiczne 23”, no. 1/2010, https://depot.ceon.pl/handle/123456789/7080, s. 242.

41 J. Szacki, Patriotyzm jako bład i jako cnota, „Gazeta Wyborcza”, 2013.

${ }^{42}$ P. Burgoński, Polski patriotyzm w dobie komunizmu. Koncepcja patriotyzmu w nauczaniu księdza Jerzego Popietuszki.
} 
Zauważyć przy tym warto, że owa lojalność, służba i ofiarność, jakie są wpisane w umiłowanie ojczyzny, nie mogą być bezmyślne. Jeżeli jednak miłość ta jest stronnicza, bywa niebezpieczna. „Na przykład Max Weber, znany socjolog niemiecki, był przekonany, że patriotyzm wyrażający się w akceptacji działania Cesarstwa Niemieckiego w czasie I wojny światowej jest ze wszech miar właściwy, bowiem stanowi on podstawę dla trwania Kultury Zachodu. Gdy z kolei inny znany socjolog francuski Emil Durkheim nawoływał w tym czasie do popierania stanowiska Francji, ponieważ jego zdaniem to ona broniła wartości cywilizacji europejskiej. Ten przykład wskazuje na dwa aspekty pojęcia patriotyzmu, które należy uwzględnić w naszej analizie. Otóż jest to eksponowanie pewnych idei, na przykład idei kultury lub idei cywilizacji, które mogą stać się nadrzędne w stosunku do pojęcia narodu. Ale gdy chęć bycia wiernym danej idei dodatkowo współgra z lojalnością wobec własnego kraju, to tym bardziej dostarcza argumentów na rzecz postawy patriotycznej” ${ }^{43}$.

Z kolei do postawy patriotycznej Jerzy Kunikowski zalicza sześć elementów:

- przywiązanie do ojczyzny,

- znajomość historii i tradycji swojego narodu,

- gotowość do obrony granic kraju, wolności ojczyzny, poszanowania ofiar w chwili jej zagrożenia,

- stosunek jednostki do prawa i obowiązków obywatelskich, do państwa oraz motywacja do pracy, nauki i łączenia celów społecznych z osobistymi,

- poczucie narodowej godności,

- poszanowanie, ochrona oraz pomnażanie dorobku narodu (chodzi nie tylko o dobra materialne $)^{44}$.

„Patriotyzm - będący więzią i dziedzictwem - jest unikatową wartością, a zarazem postawą do ludzi i zamieszkiwanej przez nich przestrzeni, do dotychczasowego losu dziejowego i poszczególnych wydarzeń, wizji przyszłości, tradycji, obyczajów i zwyczajów, do wytworów kultury, instytucji i państwa. Jest to stosunek poczucia wspólnoty, przywiązania, umiłowania, wierności i tęsknoty, szacunku, obrony i poświęcenia, poczucia odpowiedzialności za wszystko, co $\mathrm{w}$ tej zbiorowości istnieje i się dzieje, a także poczucie obowiązku działania na rzecz jej rozwoju" ${ }^{45}$. Akcentując wymiar działania właściwy patriotyzmowi, Władysław Stróżewski dodaje, że jest to ,gotowość do wzbogacania ojczyzny o wszelkie możliwe wartości, ale także do ich obrony. Gotowość ta winna być tym gorliwsza, im wyższych wartości dotyczy. Zacząć trzeba od najbardziej podstawowych: wolności, terytorium, państwa"46.

\footnotetext{
43 A. Drabarek, Kontrowersje wokót pojęcia patriotyzmu, [w:] Klasy mundurowe. Od teorii do dobrych praktyk, red. A. Skrabacz, L. Kanarski, L. Urych, Warszawa 2016, s. 29.

44 J. Kunikowski, Istota patriotyzmu, [w:] Patriotyzm współczesnych Polaków, red. A. Skrabacz, Warszawa 2012, s. 24-42.

45 I. Urych, Od kultury fizycznej do patriotyzmu i od patriotyzmu do kultury fizycznej. O ksztaltowaniu postaw w tworzeniu bezpieczeństwa narodowego, [w:] Powrót do Ojczyzny? Patriotyzm wobec nowych czasów. Kontynuacje i poszukiwania, red. C. Smuniewski, P. Sporek, Warszawa 2017, s. 368.

${ }^{46}$ W. Stróżewski, Logos, Wartość, Miłość, Znak, Kraków 2013, s. 181.
} 


\section{PATRIOTYZM SPORTOWY}

Sport jest skutecznym narzędziem promowania prawości, wolności i patriotyzmu ${ }^{47}$, jednoczy wokół pozytywnych idei, przezwycięża uprzedzenia, wzmacnia równość i ideę współpracy $^{48}$. Ideą Igrzysk Olimpijskich jest jednoczenie społeczeństw w duchu sportu oraz krzewienie kultury pokoju. Uczestnictwo w wydarzeniach sportowych wychodzi zatem poza ramy aktywności fizycznej i staje się przyczynkiem do kształtowania pozytywnych wartości. Dodatkowo, postrzegając patriotyzm jako postawę w stosunku do ludzi i zamieszkiwanej przez nich przestrzeni, do dotychczasowego losu dziejowego i poszczególnych wydarzeń, obyczajów i zwyczajów, w kontekście Igrzysk propagowana jest edukacja olimpijska. Jej istotą jest przekazanie uczniom takich treści ducha jak bezinteresowność, braterstwo, równość, które to mają szansę egzemplifikacji w zmaganiach sportowych, Olimpizm i edukacja olimpijska proponują połączenie walorów fizycznych człowieka i jego walorów estetycznych z wartościami moralnymi, tak cennymi w budowie tożsamości społecznej ${ }^{49}$.

„Poza wyżej zaprezentowanymi ideałami warto wskazać na uniwersalny i egalitarny charakter wartości zawartych w zasadzie olimpijskiej allnations - allgames (wszystkie narody - wszystkie sporty), a także na wyeksponowane w oficjalnej dewizie Międzynarodowego Komitetu Olimpijskiego wartości: citius - altius - fortius (szybciej - wyżej - silniej). W związku z powyższym do planowanych efektów edukacji olimpijskiej, która - realizując różne programy i projekty edukacyjne - kultywuje wartości olimpijskie, można zaliczyć:

- wychowanie w tolerancji dla rasy, religii, narodowości, wartości materialnych,

- egalitarność w ocenie, wynikającą z faktu, że wszyscy sportowcy są oceniani według tych samych kryteriów,

- kształtowanie przekonań o sensie pracy nad sobą, o potrzebie doskonalenia siebie i swoich wyników nie tylko w sporcie,

- dobrowolne podporządkowanie się określonym normom i przepisom gry przy jednoczesnym zachowaniu swojej indywidualności i poczucia wolności, wiary w człowieka, jego szlachetności oraz naturalne dążenie do bycia dobrym,

- kształtowanie odpowiednich relacji między ludźmi, interakcji człowiek - człowiek, człowiek - zbiorowość, zbiorowość - zbiorowość"50.

W Polsce sport od zawsze był związany z krzewieniem patriotyzmu. Pierwsze kluby sportowe, które powstały na początku XX wieku (Pogoń Lwów - 1904; Wisła Kraków 1906; Legia Warszawa - 1916), miały za zadanie, obok rywalizacji sportowej, krzewić

\footnotetext{
47 J. Żaryn, Prof. Żaryn w miesięczniku „,WSieci Historii”: , Sport ma w sobie silę, w której mieszcza się trzy wielkie wartości: Prawość, Wolność i Patriotyzm, www.wpolityce.pl, https://wpolityce.pl/polityka/184107-profzaryn-w-miesieczniku-wsieci-historii-sport-ma-w-sobie-sile-w-ktorej-mieszcza-sie-trzy-wielkie-wartosciprawosc-wolnosc-i-patriotyzm.

${ }^{48}$ I. Bokova, Sport na rzecz rozwoju i pokoju, (2016), http://www.un.org.pl/sport-na-rzecz-rozwoju-i-pokoju.

49 I. Urych, Od kultury fizycznej do patriotyzmu i od patriotyzmu do kultury fizycznej. O ksztaltowaniu postaw wtworzeniu bezpieczeństwa narodowego, [w:] Powrót do Ojczyzny? Patriotyzm wobec nowych czasów. Kontynuacje i poszukiwania, red. C. Smuniewski, P. Sporek, Warszawa 2017.

${ }^{50}$ I. Urych, Od kultury fizycznej..., s. 367-68.
} 
narodowe tradycje i promować język ojczysty ${ }^{51}$. Niewątpliwie sukcesy sportowców na arenie międzynarodowej integrują społeczeństwa i wzmacniają poczucie tożsamości narodowej, co jest dodatkowo wzmacniane przez symbole narodowe towarzyszące międzynarodowym wydarzeniom sportowym, takie jak barwy narodowe lub hymn narodowy wygrywany na cześć zwycięskiej drużyny. Dodatkowo, poczucie patriotyzmu jest wzmacniane dzięki inicjatywom sportowo-patriotycznym, np. Bieg Niepodległości lub bieg ku pamięci Żołnierzy Wyklętych ${ }^{52}$.

Nie można oczywiście idealizować sportowego patriotyzmu i ducha sportowej rywalizacji. Sportowy patriotyzm nie może być pomniejszony do kibiców ubranych w narodowe stroje i dzieci wymieniające się kartami swoich ulubionych sportowców. Jako wydarzenie generujące wysokie dochody sport przyciąga niepożądane praktyki, takie jak zmiana obywatelstwa dla korzyści materialnych, doping oraz faworyzowanie jednego kraju na niekorzyść drugiego. Nie mniej jednak warto pamiętać, że bardzo prostym wyrazem sportowej postawy patriotycznej jest po prostu świadoma i aktywna troska o rozwój swojej sprawności, zdrowia i osobowości w różnych formach kultury fizycznej, „wspólne uczestnictwo $\mathrm{w}$ otrzymanej $\mathrm{w}$ toku dziejów kulturze fizycznej, a także podtrzymanie i doskonalenie tego dziedzictwa” czy „kultywowanie ideałów edukacji olimpijskiej nie tylko w walce sportowej, lecz także w działalności obywatelskiej" ${ }^{53}$.

\section{TOLERANCJA}

Powyższa dyskusja na temat tożsamości społecznej i narodowej oraz patriotyzmu wskazuje na nierozerwalnie $\mathrm{z}$ nią związane poczucie przynależności, faworyzacji swojej grupy, współzawodnictwo, wyolbrzymianie różnic między grupami, a nawet dyskryminację członków grupy obcej. Koniecznym jest więc refleksja nad tolerancją, rozumianą jako postawę poszanowania innych, która obecnie stanowi szczególną wartość, ponieważ w globalnym świecie rozwój ekonomiczny, społeczny i osobisty coraz bardziej zależny jest od nieustannej interakcji z innymi ${ }^{54}$.

Władysław Kopaliński ${ }^{55}$ wskazuje, że tolerancja jest wyrozumiałością, liberalizmem w stosunku do cudzych wierzeń, praktyk, poglądów, działań, postaw nawet wówczas, gdy różnią się od własnych, bądź są z nimi sprzeczne. Inaczej ujmując, tolerancja to uszanowanie czyichś poglądów, zachowań, szczególnie innych niż nasze własne. Jeżeli natomiast ktoś jest tolerancyjny, to „szanuje poglądy, zachowania i gusty inne niż jego własne" ${ }^{, 56}$. Postawa taka

\footnotetext{
${ }^{51}$ M. Pisarek, Wydarzenia sportowe i sukcesy polskich sportowców zachętą do budowania tożsamości narodowej oraz postaw patriotycznych, „Studia Leopoliensia 8” 2015, s. 457-67, http://www.szyran.republika.pl/artykuly/ patriotyzm.htm.

${ }^{52}$ Ibidem.

${ }^{53}$ I. Urych, Od kultury fizycznej..., s. 369.

${ }^{54}$ N. Berggren, T. Nilsson, Globalization and the Transmission of Social Values: The Case of Tolerance, „Journal of Comparative Economics 43”, no. 2/2015, s. 371-89.

${ }^{55}$ Vide: W. Kopaliński, Stownik wyrazów obcych i zwrotów obcojęzycznych z Almamanachem, Warszawa 2000.

${ }^{56}$ M. Bańko, Inny stownikjęzyka polskiego PWN, t. 2, Warszawa 2000, s. 833.
} 
oznacza akceptację i zgodę na odmienność myśli, opinii, wiary oraz dążenie do dialogu z osobami o poglądach przeciwstawnych do tych, które prezentujemy. „Postawa taka sprawia, że człowiek stopniowo pozbywa się przekonania o tym, że jest lepszy od innych i uwalnia się od uprzedzeń, które stanowią przeszkodę na drodze dialogu i budowania wspólnoty" ${ }^{57}$.

W literaturze odnaleźć można podział tolerancji na negatywną (bierną) i pozytywną (czynną). Etymologia tego terminu (z łac. tolerare - cierpliwie znosić) powiązana jest z tolerancją negatywną, która polega na braku interwencji wobec zjawisk postrzeganych jako odmienne oraz na cierpliwym znoszeniu tego, co uznane jest za przykre lub niesłuszne ${ }^{58}$. „Tak rozumiana tolerancja jest postawą nacechowaną minimalizmem i domaga się dopełnienia przez tolerancję pozytywną lub czynną, która przekracza postawę cierpliwego znoszenia i polega na poparciu, udzielaniu preferencji, zaangażowaniu na rzecz osób i grup, obyczajów i wartości, które odbiegają od powszechnie przyjmowanych i akceptowanych w określonym środowisku. Tolerancja rozumiana w sensie pozytywnym jest postawą, która zmierza do ujednolicenia szans grup ludzi o odmiennych poglądach" ${ }^{59}$.

Wraz z rosnącą liczbą imigrantów w Polsce lub w innych krajach, a także związanym $\mathrm{z}$ tym procesem stopniowych przemian $\mathrm{w}$ strukturze społecznej, problem tolerancji nabiera szerszego znaczenia. W tym kontekście tolerancja powinna być wyrazem pozbywania się protekcjonalności i poczucia wyższości oraz dążeniem przy tym do konstruktywnego angażowania aktywności kognitywnej, afektywnej i behawioralnej w stosunku do drugiej osoby. Jednakże temat integracji imigrantów w Polsce i Europie prowadzi do polaryzacji opinii publicznej ${ }^{60}$. Jest to temat niejednokrotnie podejmowany w przestrzeni medialnej, obecny zaś w mediach obraz imigrantów może wzmocnić poziom istniejących lęków i niepokojów społecznych, m.in. poprzez oddziaływanie na uprzedzenia i stereotypy. Postawy niechęci do obcokrajowców są wtedy motywowane poczuciem realistycznego lub symbolicznego zagrożenia. $Z$ drugiej strony działania medialne i wypowiedzi osób publicznych cieszących się autorytetem mogą osłabić lęki i niepokoje społeczne oraz osłabić negatywne przekonania i zachowania w stosunku do migrantów ${ }^{61}$.

\footnotetext{
${ }^{57}$ K. Glombik, Tolerancja jako postawa moralna, „Studia Oecumenica”, 2013, s. 114.

${ }^{58}$ I. Lazari-Pawłowska, Trzy pojęcia tolerancji, „Studia Filozoficzne 8” 1984, s. 105.

${ }^{59}$ K. Glombik, Tolerancja..., s. 114-115.

60 S. Marino, S. Dawes, Introduction to Fortress Europe: Media, Migration and Borders, „Networking Knowledge 9", no. 4 2016, s. 1-6, http://eprints.bournemouth.ac.uk/29782/1/Editorial Fortress Europe.pdf.; L.Chouliaraki, M. Georgiou, R. Zaborowski, The European „Migration Crisis” and the Media A CrossEuropean Press Content Analysis, 2017, https://s3.amazonaws.com/academia.edu.documents/53658010/ Migration_and_media_report_FINAL.pdf?AWSAccessKeyId=AKIAIWOWYYGZ2Y53UL3A\&Expires $=15556$ 84741\&Signature=rel574SoaoreHAcNHUn8Ihz6fZY\%3D\&response-content-disposition=inline\%3B

filename\%3DThe_European_.; Vide: J. Jura, K. Kałużyńska, Obraz obcokrajowców i imigrantów w polskich mediach tradycyjnych $i$ internetowych, [w:] Imigranci o wysokich kwalifikacjach na polskim rynku pracy, red. J. Konieczna-Sałamatin, Warszawa 2015.

${ }_{61}$ Vide: D. Domalewska, M. Żakowska, Migracje z państw objętych konfliktami zbrojnymi - analiza wypowiedzi parlamentarzystów na Twitterze, „Przegląd Europejski 2” (2019); M. Żakowska, D. Domalewska, Factors Determining Polish Parliamentarians' Tweets on Migration: A Case Study of Poland, „Politologicky Casopis 2019", no. 3/2019.
} 
Istotę problemu dostrzegło również Zgromadzenie Ogólne ONZ, które z inicjatywy UNESCO w 1995 r. ustanowiło Międzynarodowy Dzień Tolerancji, przypadający na 16 listopada. Po tym wydarzeniu kraje członkowskie UNESCO przyjęły Deklarację na Temat Zasad Tolerancji, której Artykuł I brzmi: „Tolerancja to szacunek, akceptacja i uznanie bogactwa różnorodności kultur na świecie, naszych form wyrazu i sposobów na bycie człowiekiem. Sprzyja jej wiedza, otwartość, komunikowanie się oraz wolność słowa, sumienia i wiary. Tolerancja jest harmonią w różnorodności. To nie tylko moralny obowiązek, ale także prawny i polityczny warunek. Tolerancja - wartość, która czyni możliwym pokój - przyczynia się do zastąpienia kultury wojny kulturą pokoju"62.

Należy podkreślić, że badania nad tolerancją mają długą tradycję, a zmieniająca się struktura demograficzna i społeczna społeczeństw przyczyniła się do rozwoju badań nad tolerancją $\mathrm{w}$ społeczeństwach wielokulturowych. Szeroko zakrojone badania dotyczące wpływu wskaźników politycznych, gospodarczych i społecznych na tolerancję oraz uprzedzenia prowadzone były w wielu ośrodkach naukowych za granicą i w Polsce ${ }^{63}$. Prekursorem badań społecznych w tej dziedzinie był Emory Bogardus ${ }^{64}$, który analizował dystans społeczny rozumiany jako stopień zrozumienia między dwiema jednostkami lub między jednostką a grupą. Na skutek kontaktu osobistego lub międzygrupowego z odmiennym systemem kulturowym zachodzi proces akulturacji, czyli społeczna i psychologiczna integracja jednostki ze społeczeństwem przyjmującym. Proces akulturacji tworzy kontinuum na osi bliskość - społeczny i psychologiczny dystans. Jak zauważa John W. Berry ${ }^{65}$, kontakt międzygrupowy prowadzi do dylematu, czy zachować własną tożsamość kulturową, czy zacieśnić kontakt międzykulturowy i aktywnie uczestniczyć w życiu społecznym grupy dominującej. W zależności od rozwiązania tego dylematu Berry opracował cztery orientacje akulturacyjne: integrację, asymilację, separację i marginalizację. Zdaniem Haliny Grzymały-Moszczyńskiej ${ }^{66}$ integracja jest najbardziej pożądaną orientacją akulturacyjną, ponieważ wchodząc w kontakt z kulturą dominującą jednostka jednocześnie utrzymuje własną tożsamość kulturową.

\footnotetext{
${ }^{62}$ UNIC Warsaw, http://www.unic.un.org.pl/dyskryminacja/tolerancja-poszanowanie.php, (16.08.2019).

${ }^{63}$ N. Berggren, T. Nilsson, Tolerance in the United States: Does Economic Freedom Transform Racial, Religious, Political and Sexual Attitudes?, „European Journal of Political Economy 45” 2016, s. 53-70; T.J. Hatton, Public Opinion on Immigration: Has the Recession Changed Minds?, „Economic Policy" 86/2016, s. 205-46; S. Wong et al., Immigrant Influx and Generational Politics: A Comparative Case Study of Hong Kong and Taiwan, „Electoral Studies” 58/2019, s. 84-93; M. Zielińska, D, Szaban, Od tolerancji nowoczesnej do ponowoczesnej. Dynamika i uwarunkowania postaw wobec imigrantów i mniejszości narodowych wśród mieszkańców województwalubuskiego w latach 2005-2014, „Studia Humanistyczne AGH” 16 no. 1/2017, s. 721; Vide: K. Andrejuk, Postawy wobec imigrantów w świetle wyników europejskiego sondażu społecznego 2014-2015. Polska na tle Europy, Warszawa 2015, https://depot.ceon.pl/handle/123456789/12510.

64 E.S. Bogardus, Social Distance and Its Origins, „Sociology\&Social Research” 9/1925, s. 216-25; E.S. Bogardus, Racial Distance Changes in the United States during the Past 30 Years. - PsycNET, „Sociology\&Social Research” 43/1958, s. 127-34, https://psycnet.apa.org/record/1960-01208-001.

65 J.W. Berry, A Psychology of Immigration, ,Journal of Social Issues” 57 no. 3/2001, s. 615-31.

${ }^{66}$ H. Grzymała-Moszczyńska, Uchodźcy. Podręcznik dla osób pracujących z uchodźcami, Kraków 2000, s. 18-19.
} 


\section{METODOLOGIA BADAŃ}

Przedmiotem prowadzonych badań empirycznych były zależności zachodzące między tożsamością narodową, patriotyzmem, sportowym patriotyzmem i tolerancją uczniów klas wojskowych w Polsce i studentów wojskowej uczelni wyższej. Celem poznawczym było opisanie, zdiagnozowanie i wyjaśnienie zależności między wartościami związanymi z tożsamością narodową, patriotyzmem, sportowym patriotyzmem i tolerancją badanych. Celem teoretycznym było wzbogacenie systemu teoretycznej wiedzy społecznej związanej z procesami konstruowania tożsamości, celem praktycznym natomiast było stworzenie na podstawie uzyskanych wyników badań rekomendacji dla praktyki społecznej (edukacyjnej, kulturalnej) w zakresie konstruowania tożsamości narodowej młodych ludzi, zwłaszcza uczniów klas wojskowych i studentów uczelni wojskowych, będącej istotnym elementem bezpieczeństwa narodowego. Dla realizacji powyższych celów określono główny problem badawczy w postaci pytania: W jakim zakresie zachodzi zależność między tożsamością narodową, patriotyzmem, sportowym patriotyzmem i tolerancją młodych Polaków? Postawiono także problemy szczegółowe:

(1) Czym charakteryzuje się tożsamość narodowa, patriotyzm, sportowy patriotyzm i tolerancja badanych?

(2) Jaka jest zależność pomiędzy skalami tożsamości narodowej, patriotyzmu, sportowego patriotyzmu i tolerancji badanych?

(3) Czy i w jakim zakresie wiek, płeć i miejsce zamieszkania determinują poczucie tożsamości narodowej, patriotyzmu, sportowego patriotyzmu i tolerancji badanych?

Przyjęto następujące hipotezy: Poczucie tożsamości narodowej badanych charakteryzuje się poczuciem konieczności czczenia naszej narodowej historii i dziedzictwa, patriotyzm związany jest z miłością do ojczyzny, sportowy patriotyzm łączy się z kibicowaniem Polsce na międzynarodowych zawodach sportowych, tolerancja zaś jest związana $\mathrm{z}$ akceptacją na osiedlanie się w Polsce osób bliskich nam kulturowo, np. z Ukrainy $\left(\mathrm{H}_{1}\right)$. Istnieje znaczna (powyżej 0,5) współzależność między tożsamością narodową, patriotyzmem, tolerancją i sportowym patriotyzmem badanej młodzieży $\left(\mathrm{H}_{2}\right)$. Założono, że wiek, płeć i miejsce zamieszkania wpływają znacząco na poczucie tożsamości narodowej, tolerancji i sportowego patriotyzmu $\left(\mathrm{H}_{3}\right)$.

Badaniom empirycznym poddano następujące zmienne: tożsamość narodowa, patriotyzm, tolerancja i sportowy patriotyzm (zmienne dychotomiczne) oraz wiek, płeć i miejsce zamieszkania (zmienne niezależne).

W badaniach wykorzystano metodę sondażu diagnostycznego przy pomocy techniki ankiety i kwestionariusza ankiety jako narzędzia badawczego. Kwestionariusz ankiety składał się ze skali patriotyzmu, tożsamości narodowej, sportowego patriotyzmu (opracowanych w oparciu o ankietę Billings et $a l .{ }^{67}$ ), tolerancji oraz metryczki. Poszczególne pytania znajdujące się w kwestionariuszu zostały przedstawione w dalszej części artykułu. Badaniem

\footnotetext{
${ }^{67}$ A.C. Billings, K.A. Brown, N.A. Brown, 5,535 Hours of Impact: Effects of Olympic Media on Nationalism
} Attitudes. 
objęto 508 respondentów - uczniów drugich i trzecich klas szkoły średniej, którzy należą do tzw. klas wojskowych ${ }^{68}$, oraz studentów pierwszego roku jednej z warszawskich uczelni Akademii Sztuki Wojennej. Dobór badanych był incydentalny (badanie przeprowadzono wśród ochotników), celowy - obie grupy badanych realizują program szeroko rozumianej edukacji dla bezpieczeństwa, wzbogacony o tematykę związaną z obronnością kraju czy historią oręża polskiego, $\mathrm{z}$ tą różnicą, że klasy wojskowe realizują ten program na etapie szkoły średniej, studenci zaś na etapie szkoły wyższej. Dobór szkół natomiast był losowy. Badania przeprowadzono w okresie 15 stycznia do 15 kwietnia 2019 r. Zależności między zmiennymi zbadano przy pomocy następujących testów statystycznych: odchylenie standardowe, test korelacji między zmiennymi, test chi $^{2}$.

\section{SKALA TOŻSAMOŚCI NARODOWEJ, PATRIOTYZMU, SPORTOWEGO PATRIOTYZMU I TOLERANCJI - ANALIZA WYNIKÓW BADAŃ}

W grupie 508 ankietowanych było 174 kobiet (34,25\%) i 334 mężczyzn (65,75\%). Wśród ankietowanych dominowały osoby w wieku 16-18 lat (68,50\%), gdy pozostali badani byli w wieku 19-29 lat (31,50\%). Badani pochodzili ze wsi i małych miast (47,24\%), miast 50-100 tys. (30,71\%) oraz większych $(22,05 \%)$. Wyniki skali tożsamości narodowej, patriotyzmu i sportowego patriotyzmu nie były zróżnicowane, a ich średnia wartość wynosiła powyżej średniej 4 przy standardowym odchyleniu nie przekraczającym 0,62 . Z kolei skala tolerancji miała najniższą średnią $(3,48)$ z najwyższym odchyleniem standardowym, co wskazuje na duże zróżnicowanie odpowiedzi udzielanych przez respondentów.

\begin{tabular}{|c|c|c|c|}
\hline SKALA & STWIERDZENIA & Średnia & $\mathrm{SD}$ \\
\hline \multirow{6}{*}{$\begin{array}{l}\text { SKALA } \\
\text { TOŻSAMOŚCI } \\
\text { NARODOWEJ } \\
\text { Średnia }=4,07 \\
\text { SD }=0,62\end{array}$} & Trzeba zawsze czcić naszą narodową historię i dziedzictwo. & 4,73 & $\mathbf{0 , 5 7}$ \\
\hline & $\begin{array}{l}\text { Mój kraj ma specjalną misję do spełnienia w Europie dzięki } \\
\text { wartościom przez nas wyznawanym. }\end{array}$ & 4,10 & 0,95 \\
\hline & $\begin{array}{l}\text { Mój kraj powinien bardziej stanowczo narzucać wartości i zasady } \\
\text { innym krajom, jeżeli te wartości i zasady są dobre. }\end{array}$ & 3,81 & 1,06 \\
\hline & $\begin{array}{l}\text { Mój kraj mógłby więcej osiągnąć, gdyby pozwolił na większy } \\
\text { wpływ z zagranicy. }\end{array}$ & 3,68 & 1,27 \\
\hline & Nie chciałbym mieszkać na stałe w innym kraju niż Polska. & 3,88 & 1,20 \\
\hline & $\begin{array}{l}\text { W czasie międzynarodowych zawodów sportowych przedstawiciele } \\
\text { mojego kraju na pewno przestrzegają zasad fair play. }\end{array}$ & 4,20 & 0,84 \\
\hline \multirow{6}{*}{$\begin{array}{l}\text { SKALA } \\
\text { PATRIOTYZMU }\end{array}$} & Kocham swój kraj. & 4,70 & 0,59 \\
\hline & Jestem dumny, że pochodzę ze swojego kraju. & 4,71 & 0,56 \\
\hline & $\begin{array}{l}\text { Jestem przywiązany do swojego kraju i głęboko dotyka mnie } \\
\text { wszystko, co tyczy się mojego kraju. }\end{array}$ & 4,28 & 0,86 \\
\hline & $\begin{array}{l}\text { Chociaż nie zawsze zgadzam się z działaniami rządu, czuję się silnie } \\
\text { przywiązany do swojego kraju. }\end{array}$ & 4,19 & 0,91 \\
\hline & Trzeba zawsze służyć swojemu krajowi. & 4,39 & 0,88 \\
\hline & $\begin{array}{l}\text { Czuję się dumny, gdy sportowcy z mojego kraju odnoszą } \\
\text { sukcesy na międzynarodowych zawodach sporttowych. }\end{array}$ & 4,79 & $\mathbf{0 , 5 0}$ \\
\hline
\end{tabular}

${ }^{68}$ I. Urych, Military Classes as an Area of Interest for the Armed Forces of the Republic of Poland. Experience and Perspectives, „Defense Resources Management 17”, no. 2 (2018). 


\begin{tabular}{|l|l|c|c|}
\hline $\begin{array}{l}\text { SKALA } \\
\text { SPORTOWEGO } \\
\text { PATRIOTYZMU }\end{array}$ & $\begin{array}{l}\text { Zawsze kibicuję Polsce na międzynarodowych zawodach } \\
\text { sportowych (np. Igrzyska Olimpijskie, Mundial itp.). }\end{array}$ & 4,62 & 0,63 \\
\cline { 2 - 4 } $\begin{array}{l}\text { Zawsze kibicuję lepszej drużynie, nawet jeżeli jej przeciwnikiem } \\
\text { SD=0,55 }\end{array}$ & $\begin{array}{l}\text { Zast Polska. } \\
\text { jest }\end{array}$ & $\begin{array}{l}\text { Czuję się dumny, kiedy mój kraj wygrywa w } \\
\text { międzynarodowych zawodach sportowych. }\end{array}$ & 1,53 \\
\hline $\begin{array}{l}\text { SKALA } \\
\text { TOLERANCJI }\end{array}$ & $\begin{array}{l}\text { Powinniśmy zezwalać na osiedlanie się w Polsce osób bliskich nam } \\
\text { kulturowo, np. z Ukrainy. }\end{array}$ & $\mathbf{4 , 7 8}$ & $\mathbf{0 , 5 6}$ \\
\cline { 2 - 4 } $\begin{array}{l}\text { Średnia=3,48 } \\
\text { SD=0,92 }\end{array}$ & $\begin{array}{l}\text { Powinniśmy zezwalać na osiedlanie się w Polsce osób o odmiennej } \\
\text { kulturze, religii, np. muzułmanów. }\end{array}$ & 2,94 & 1,17 \\
\cline { 2 - 4 } & $\begin{array}{l}\text { Powinniśmy zezwalać na osiedlanie się w Polsce osób z wysoko } \\
\text { rozwiniętych krajów z Europy, np. Francji. }\end{array}$ & 3,67 & 1,08 \\
\cline { 2 - 4 } & $\begin{array}{l}\text { Powinniśmy zezwalać na osiedlanie się w Polsce osób z biednych } \\
\text { krajów z Europy, np. z Mołdawii. }\end{array}$ & 3,37 & 1,18 \\
\cline { 2 - 4 } & $\begin{array}{l}\text { Zawsze staram się traktować drugiego czlowieka szacunkiem, } \\
\text { nawet jeżeli jego poglądy i zwyczaje są odmienne od moich. }\end{array}$ & $\mathbf{4 , 1 2}$ & $\mathbf{0 , 9 8}$ \\
\hline
\end{tabular}

Tabela 1. Wartości średnie i odchylenie standardowe dla poszczególnych skali i ich składowych Źródło: badania własne

\section{SKALA TOŻSAMOŚCI NARODOWEJ}

$\mathrm{Na}$ podstawie przeprowadzonych badań stwierdzić można, że ankietowani byli przekonani o konieczności czczenia historii narodowej i dziedzictwa (78,35\%). W mniejszym stopniu badani byli przekonani, że nie chcą mieszkać na stałe poza Polską (43,71\%), jak również co do gry fair play polskich sportowców (43,31\%), a także poczucia misji naszego narodu w Europie (42,91\%). Najrzadziej badani potwierdzali, że Polska powinna bardziej stanowczo narzucać własne wartości i zasady innym krajom $(32,29 \%)$, co pozwoliłoby na większe osiągnięcia $(36,61 \%)$.

\section{SKALA PATRIOTYZMU}

Analiza wyników badań dowodzi, że ankietowani mają poczucie dumy sportowej (83,07\%), dumy z bycia Polakiem (75,59\%), są świadomi swojej miłości do Ojczyzny $(74,41 \%)$ oraz deklarują wierną służbę Polsce $(60,63 \%)$. W mniejszym stopniu badani charakteryzowali siebie jako osoby przywiązane do kraju (50,76\%), szczególnie w sytuacji braku akceptacji działań podejmowanych przez rząd (47,64\%).

\section{SKALA SPORTOWEGO PATRIOTYZMU}

Analiza skali sportowego patriotyzmu wskazuje, że w sytuacji rozgrywek sportowych badani kibicowali zdecydowanie „swoim” (68,50\%), czując dumę z wygranej (83,07\%). Ankietowani zdecydowanie nie kibicowali lepszej drużynie od Polski $(35,43 \%)$. 


\section{SKALA TOLERANCJI}

W zakresie tolerancji badani wskazali, że przede wszystkim zawsze starają się traktować drugiego człowieka szacunkiem, nawet jeżeli jego poglądy i zwyczaje są odmienne od ich własnych (zdecydowanie tak 39,76\%, raczej tak 44,88\%). W pozostałych aspektach ankietowani najczęściej wskazali odpowiedź: trudno powiedzieć. Najczęściej badani sprzeciwiali się osiedlaniu osób o odmiennej kulturze i religii (37,79\%), jak również bliskich kulturowo $(22,84 \%)$ czy z krajów biedniejszych (20,87\%). Ankietowani najmniej byli przeciwni osiedlaniu się osób z krajów wysokorozwiniętych Europy $(11,42 \%)$, gdy ponad połowa badanych należała do zwolenników.

\section{TOŻSAMOŚĆ NARODOWA, PATRIOTYZM, SPORTOWY PATRIOTYZM}

\section{TOLERANCJA W ŚWIETLE ANALIZY WYNIKÓW PRZEPROWADZONYCH BADAŃ}

$\mathrm{Na}$ podstawie wyników przeprowadzonych badań wykazano, że ankietowani przede wszystkim posiadali silne poczucie dumy $\mathrm{z}$ odnoszących sukcesy polskich sportowców $(4,79 \pm 0,50)$ oraz samych sukcesów sportowych kraju $(4,78 \pm 0,56)$. Potwierdzono postawę szacunku dla narodowej historii i dziedzictwa $(4,73 \pm 0,57)$ oraz drugiego człowieka i jego odmiennych poglądów i zwyczajów $(4,12 \pm 0,98)$. Stwierdzono, że ankietowani charakteryzowali się przede wszystkim patriotyzmem $(4,51 \pm 0,54)$, w mniejszym stopniu tożsamością narodową $(4,07 \pm 0,62)$ i patriotyzmem sportowym $(4,01 \pm 0,55)$, a prezentowany przez nich poziom tolerancji $(3,48 \pm 0,92)$ był najniższy i postawy w tym aspekcie były najsilniej zróżnicowane.

Analiza wyników badań zawartych w tabeli drugiej pozwala na sformułowanie następujących wniosków:

- Skala tożsamości narodowej istotnie korelowała ze skalą patriotyzm, sportowego patriotyzmu i tolerancji;

- Skala patriotyzmu znacząco wpływała na wyniki skali tożsamości narodowej i sportowego patriotyzmu, nie różnicowała natomiast postawy tolerancji;

- Skala sportowego patriotyzmu istotnie korelowała ze skalą patriotyzmu, tożsamości narodowej i tolerancji;

- Skala tolerancji istotnie korelowała ze skalą patriotyzmu, sportowego patriotyzmu i tożsamości narodowej.

\begin{tabular}{|c|c|c|c|c|c|}
\hline & & $\begin{array}{c}\text { Skala } \\
\text { patriotyzmu }\end{array}$ & $\begin{array}{c}\text { Skala } \\
\text { tożsamości } \\
\text { narodowej }\end{array}$ & $\begin{array}{c}\text { Skala } \\
\text { sportowego } \\
\text { patriotyzmu }\end{array}$ & $\begin{array}{c}\text { Skala } \\
\text { tolerancji }\end{array}$ \\
\cline { 5 - 6 } $\begin{array}{c}\text { Skala tożsamości } \\
\text { narodowej }\end{array}$ & {$[\mathrm{r}]$} & $\mathbf{0 , 5 6 7 2}$ & & $\mathbf{0 , 3 7 0 4}$ & $\mathbf{0 , 2 3 4 1}$ \\
\cline { 2 - 4 } & {$[\mathrm{p}]$} & $\mathbf{0 , 0 0 0}$ & & $\mathbf{0 , 0 0 0}$ & $\mathbf{0 , 0 0 0}$ \\
\hline \multirow{2}{*}{ Skala patriotyzmu } & {$[\mathrm{r}]$} & & $\mathbf{0 , 5 6 7 2}$ & $\mathbf{0 , 2 8 5 4}$ & NS \\
\cline { 2 - 2 } & {$[\mathrm{p}]$} & & $\mathbf{0 , 0 0 0}$ & $\mathbf{0 , 0 0 0}$ & 0,291 \\
\hline $\begin{array}{c}\text { Skala } \\
\text { sportowego } \\
\text { patriotyzmu }\end{array}$ & {$[\mathrm{r}]$} & $\mathbf{0 , 2 8 5 4}$ & $\mathbf{0 , 3 7 0 4}$ & & $\mathbf{0 , 2 7 8 4}$ \\
\cline { 2 - 3 } \cline { 5 - 6 } & {$[\mathrm{p}]$} & $\mathbf{0 , 0 0 0}$ & $\mathbf{0 , 0 0 0}$ & & $\mathbf{0 , 0 0 0}$ \\
\hline
\end{tabular}




\begin{tabular}{|c|c|c|c|c|c|}
\hline \multirow{2}{*}{$\begin{array}{c}\text { Skala } \\
\text { tolerancji }\end{array}$} & {$[\mathrm{r}]$} & NS & $\mathbf{0 , 2 3 4 1}$ & $\mathbf{0 , 2 7 8 4}$ & \\
\cline { 2 - 4 } & {$[\mathrm{p}]$} & 0,291 & $\mathbf{0 , 0 0 0}$ & $\mathbf{0 , 0 0 0}$ & \\
\hline
\end{tabular}

Tabela 2. Zależności pomiędzy skalami

Źródło: badania własne

Ponadto stwierdzić należy, że w niektórych skalach płeć istotnie różnicowała opinie badanych (zob. tabela 3).

Mężczyźni charakteryzowali się znacząco wyższym poziomem poczucia patriotyzmu w zakresie miłości i dumy z Ojczyzny, chociaż nie zawsze zgadzają się z działaniami rządu. W zakresie tożsamości narodowej potwierdzili szacunek do historii i dziedzictwa narodowego oraz przypisywali Polsce specjalną misję w Europie. W sportowej rywalizacji częściej stoją po stronie „naszych” nawet z perspektywą przegranej.

Kobiety wykazały się znacząco wyższym poziomem tolerancji i akceptacji wobec innych narodów i kultur, częściej przyjmując postawę otwartości na osiedlanie się w Polsce osób innych narodowości bez względy na pochodzenie i przyczynę.

\begin{tabular}{|c|c|c|c|c|c|c|c|}
\hline \multirow{2}{*}{ SKALA } & \multirow{2}{*}{ STWIERDZENIA } & \multicolumn{2}{|c|}{ KOBIETY } & \multicolumn{2}{|c|}{ MĘŻCZYŹNI } & \multicolumn{2}{|c|}{ Test $c h i^{2}$} \\
\hline & & Średnia & $\mathrm{SD}$ & Średnia & SD & {$[\mathrm{r}]$} & {$[\mathrm{p}]$} \\
\hline \multirow{6}{*}{ 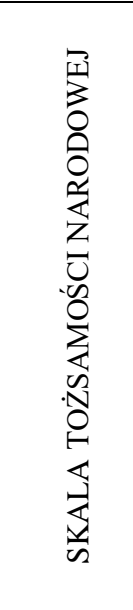 } & $\begin{array}{l}\text { Trzeba zawsze czcić naszą narodową historię i } \\
\text { dziedzictwo. }\end{array}$ & 4,60 & 0,66 & 4,80 & 0,51 & 0,1712 & 0,006 \\
\hline & $\begin{array}{l}\text { Mój kraj ma specjalną misję do spełnienia w } \\
\text { Europie dzięki wartościom przez nas } \\
\text { wyznawanym. }\end{array}$ & 3,89 & 0,89 & 4,22 & 0,96 & 0,1651 & 0,008 \\
\hline & $\begin{array}{l}\text { Mój kraj powinien bardziej stanowczo narzucać } \\
\text { wartości i zasady innym krajom, jeżeli te } \\
\text { wartości i zasady są dobre. }\end{array}$ & 3,66 & 1,08 & 3,89 & 1,05 & NS & 0,100 \\
\hline & $\begin{array}{l}\text { Mój kraj mógłby więcej osiągnać, gdyby } \\
\text { pozwolił na większy wpływ z zagranicy. }\end{array}$ & 3,77 & 1,06 & 3,63 & 1,37 & NS & 0,422 \\
\hline & $\begin{array}{l}\text { Nie chciałbym mieszkać na stałe w innym kraju } \\
\text { niż Polska. }\end{array}$ & 3,70 & 1,16 & 3,97 & 1,22 & NS & 0,091 \\
\hline & $\begin{array}{l}\text { W czasie międzynarodowych zawodów } \\
\text { sportowych przedstawiciele mojego kraju na } \\
\text { pewno przestrzegają zasad fair play. }\end{array}$ & 4,25 & 0,81 & 4,18 & 0,85 & NS & 0,509 \\
\hline \multirow{6}{*}{ 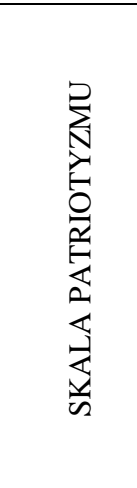 } & Kocham swój kraj. & 4,57 & 0,62 & 4,76 & 0,53 & 0,1555 & 0,013 \\
\hline & Jestem dumny, że pochodzę ze swojego kraju. & 4,57 & 0,62 & 4,78 & 0,52 & $\mathbf{0 , 1 7 1 8}$ & 0,006 \\
\hline & $\begin{array}{l}\text { Jestem przywiązany do swojego kraju i głęboko } \\
\text { dotyka mnie wszystko, co tyczy się mojego } \\
\text { kraju. }\end{array}$ & 4,18 & 0,86 & 4,32 & 0,87 & NS & 0,223 \\
\hline & $\begin{array}{l}\text { Chociaż nie zawsze zgadzam się z działaniami } \\
\text { rządu, czuję się silnie przywiązany do swojego } \\
\text { kraju. }\end{array}$ & 4,02 & 0,85 & 4,28 & 0,92 & 0,1357 & 0,031 \\
\hline & Trzeba zawsze służyć swojemu krajowi. & 4,38 & 0,98 & 4,40 & 0,83 & NS & 0,851 \\
\hline & $\begin{array}{l}\text { Czuję się dumny, gdy sportowcy z mojego kraju } \\
\text { odnoszą sukcesy na międzynarodowych } \\
\text { zawodach sportowych. }\end{array}$ & 4,82 & 0,47 & 4,77 & 0,52 & NS & 0,514 \\
\hline
\end{tabular}




\begin{tabular}{|c|l|c|c|c|c|c|c|}
\hline & $\begin{array}{l}\text { Zawsze kibicuję Polsce na międzynarodowych } \\
\text { zawodach sportowych (np. Igrzyska Olimpijskie, } \\
\text { Mundial itp.). }\end{array}$ & 4,63 & 0,61 & 4,61 & 0,64 & $\mathrm{NS}$ & 0,797 \\
\cline { 2 - 8 } & $\begin{array}{l}\text { Zawsze kibicuję lepszej drużynie, nawet jeżeli jej } \\
\text { przeciwnikiem jest Polska. }\end{array}$ & 2,90 & 1,52 & 2,11 & 1,43 & $\mathbf{0 , 2 4 4 7}$ & $\mathbf{0 , 0 0 0}$ \\
\cline { 2 - 8 } & $\begin{array}{l}\text { Czuję się dumny, kiedy mój kraj wygrywa w } \\
\text { mędzynarodowych zawodach sportowych. }\end{array}$ & 4,76 & 0,53 & 4,78 & 0,57 & $\mathrm{NS}$ & 0,726 \\
\hline \multirow{2}{*}{$\begin{array}{l}\text { Powinniśmy zezwalać na osiedlanie się w Polsce osób } \\
\text { bliskich nam kulturowo, np. z Ukrainy. }\end{array}$} & 3,44 & 1,18 & 3,01 & 1,12 & $\mathbf{0 , 1 7 4 8}$ & $\mathbf{0 , 0 0 5}$ \\
\hline & $\begin{array}{l}\text { Powinniśmy zezwalać na osiedlanie się w Polsce osób } \\
\text { o odmiennej kulturze, religii, np. muzułmanów. }\end{array}$ & 3,16 & 1,44 & 2,53 & 1,25 & $\mathbf{0 , 2 1 1 6}$ & $\mathbf{0 , 0 0 1}$ \\
\cline { 2 - 8 } & $\begin{array}{l}\text { Powinniśmy zezwalać na osiedlanie się w Polsce osób } \\
\text { z wysoko rozwiniętych krajów z Europy, np. Francji. }\end{array}$ & 3,77 & 1,07 & 3,48 & 1,08 & $\mathbf{0 , 1 2 7 8}$ & $\mathbf{0 , 0 4 2}$ \\
\hline & $\begin{array}{l}\text { Powinniśmy zezwalać na osiedlanie się w Polsce osób } \\
\text { z biednych krajów z Europy, np. z Mołdawii }\end{array}$ & 3,52 & 1,14 & 3,08 & 1,20 & $\mathbf{0 , 1 7 7 8}$ & $\mathbf{0 , 0 0 4}$ \\
\hline & $\begin{array}{l}\text { Zawsze staram się traktować drugiego człowieka } \\
\text { szacunkiem, nawet jeżeli jego poglądy i zwyczaje są } \\
\text { odmienne od moich. }\end{array}$ & 4,07 & 0,99 & 4,23 & 0,96 & $\mathrm{NS}$ & 0,224 \\
\hline
\end{tabular}

Tabela 3. Wartości średnie i odchylenie standardowe dla poszczególnych skali i ich składowych wśród kobiet i mężczyzn

Źródło: badania własne

Analiza badań wskazuje także, że w niektórych skalach wiek istotnie różnicował postawę badanych (zob. tabela 4 ).

Osoby w wieku 16-18 lat częściej potwierdzały swoją miłość do Ojczyzny, przypisując jej misję w Europie, optując za narzuceniem naszych wartości i zasad narodowych innym krajom, co pozwoli na osiągnięcie sukcesu na scenie międzynarodowej. W sportowej rywalizacji częściej stoją po stronie „naszych” nawet z perspektywą przegranej. Jednoczenie badani pomiędzy 16 a 18 rokiem życia wykazali się znacząco wyższym poziomem tolerancji i akceptacji wobec innych narodów i kultur, częściej przyjmując postawę otwartości na osiedlanie się w Polsce osób innych narodowości bez względy na pochodzenie i przyczynę.

\begin{tabular}{|c|c|c|c|c|c|c|c|}
\hline \multirow{2}{*}{ SKALA } & \multirow{2}{*}{ STWIERDZENIA } & \multicolumn{2}{|c|}{ 16-18 lat } & \multicolumn{2}{|c|}{ 19-29 lat } & \multicolumn{2}{|c|}{ Test chi $^{2}$} \\
\hline & & Średnia & $\mathrm{SD}$ & Średnia & SD & {$[\mathrm{r}]$} & [p] \\
\hline \multirow{6}{*}{ 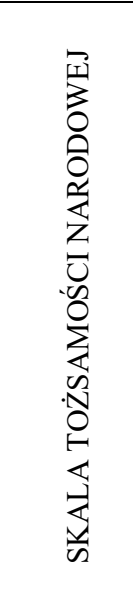 } & $\begin{array}{l}\text { Trzeba zawsze czcić naszą narodową historię i } \\
\text { dziedzictwo. }\end{array}$ & 4,76 & 0,53 & 4,66 & 0,64 & NS & 0,185 \\
\hline & $\begin{array}{l}\text { Mój kraj ma specjalną misję do spełnienia w } \\
\text { Europie dzięki wartościom przez nas } \\
\text { wyznawanym. }\end{array}$ & 4,58 & 0,86 & 3,34 & 0,92 & 0,3763 & $\mathbf{0 , 0 0 0}$ \\
\hline & $\begin{array}{l}\text { Mój kraj powinien bardziej stanowczo narzucać } \\
\text { wartości i zasady innym krajom, jeżeli te } \\
\text { wartości i zasady są dobre. }\end{array}$ & 3,95 & 0,98 & 3,49 & 1,16 & 0,2044 & 0,001 \\
\hline & $\begin{array}{l}\text { Mój kraj mógłby więcej osiągnąć, gdyby } \\
\text { pozwolił na większy wpływ z zagranicy. }\end{array}$ & 3,87 & 1,27 & 3,27 & 1,19 & 0,2170 & $\mathbf{0 , 0 0 0}$ \\
\hline & $\begin{array}{l}\text { Nie chciałbym mieszkać na stałe w innym kraju } \\
\text { niż Polska. }\end{array}$ & 3,93 & 1,23 & 3,76 & 1,15 & NS & 0,301 \\
\hline & $\begin{array}{l}\text { W czasie międzynarodowych zawodów } \\
\text { sportowych przedstawiciele mojego kraju na } \\
\text { pewno przestrzegają zasad fair play. }\end{array}$ & 4,32 & 0,78 & 3,95 & 0,90 & 0,2067 & 0,001 \\
\hline
\end{tabular}




\begin{tabular}{|c|c|c|c|c|c|c|c|}
\hline \multirow{6}{*}{ 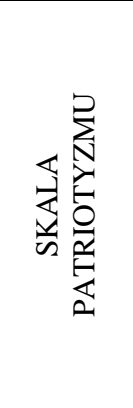 } & Kocham swój kraj. & 4,80 & 0,47 & 4,47 & 0,69 & 0,2653 & $\mathbf{0 , 0 0 0}$ \\
\hline & Jestem dumny, że pochodzę ze swojego kraju. & 4,75 & 0,51 & 4,63 & 0,66 & NS & 0,109 \\
\hline & $\begin{array}{l}\text { Jestem przywiązany do swojego kraju i głęboko } \\
\text { dotyka mnie wszystko, co tyczy się mojego kraju. }\end{array}$ & 4,30 & 0,91 & 4,22 & 0,75 & NS & 0,528 \\
\hline & $\begin{array}{l}\text { Chociaż nie zawsze zgadzam się z działaniami rządu, } \\
\text { czuję się silnie przywiązany do swojego kraju. }\end{array}$ & 4,26 & 0,94 & 4,04 & 0,82 & NS & 0,064 \\
\hline & Trzeba zawsze służyć swojemu krajowi. & 4,45 & 0,80 & 4,26 & 1,03 & NS & 0,108 \\
\hline & $\begin{array}{l}\text { Czuję się dumny, gdy sportowcy z mojego kraju } \\
\text { odnoszą sukcesy na międzynarodowych zawodach } \\
\text { sportowych. }\end{array}$ & 4,79 & 0,54 & 4,79 & 0,41 & NS & 0,998 \\
\hline \multirow{3}{*}{ 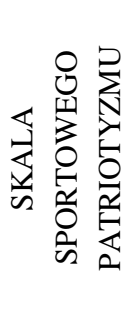 } & $\begin{array}{l}\text { Zawsze kibicuję Polsce na międzynarodowych } \\
\text { zawodach sportowych (np. Igrzyska Olimpijskie, } \\
\text { Mundial itp.) }\end{array}$ & 4,63 & 0,61 & 4,60 & 0,67 & NS & 0,756 \\
\hline & $\begin{array}{l}\text { Zawsze kibicuję lepszej drużynie, nawet jeżeli jej } \\
\text { przeciwnikiem jest Polska. }\end{array}$ & 1,85 & 1,54 & 2,99 & 1,19 & $\mathbf{0 , 3 4 7 3}$ & $\mathbf{0 , 0 0 0}$ \\
\hline & $\begin{array}{l}\text { Czuję się dumny, kiedy mój kraj wygr } \\
\text { międzynarodowych zawodach sportow }\end{array}$ & 4,76 & 0,61 & 4,81 & 0,42 & NS & 0,474 \\
\hline \multirow{5}{*}{ 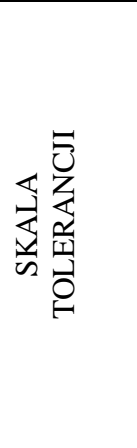 } & $\begin{array}{l}\text { Powinniśmy zezwalać na osiedlanie się w Polsce osób } \\
\text { bliskich nam kulturowo, np. z Ukrainy. }\end{array}$ & 3,46 & 1,17 & 2,94 & 1,11 & 0,2070 & 0,001 \\
\hline & $\begin{array}{l}\text { Powinniśmy zezwalać na osiedlanie się w Polsce osób } \\
\text { o odmiennej kulturze, religii, np. muzułmanów. }\end{array}$ & 3,19 & 1,47 & 2,40 & 1,10 & 2609 &, 000 \\
\hline & $\begin{array}{l}\text { Powinniśmy zezwalać na osiedlanie się w Polsce osób } \\
\text { z wysoko rozwiniętych krajów z Europy, np. Francji. }\end{array}$ & 3,80 & 1,11 & 3,39 & 0,95 & 0,1801 & 0,004 \\
\hline & $\begin{array}{l}\text { Powinniśmy zezwalać na osiedlanie się w Polsce osób } \\
\text { z biednych krajów z Europy, np. z Mołdawii. }\end{array}$ & 3,54 & 1,21 & 3,00 & 1,01 & 0,2134 & 0,001 \\
\hline & $\begin{array}{l}\text { Zawsze staram się traktować drugiego człowieka } \\
\text { szacunkiem, nawet jeżeli jego poglądy i zwyczaje są } \\
\text { odmienne od moich. }\end{array}$ & 4,13 & 1,05 & 4,11 & 0,81 & NS & 0,882 \\
\hline
\end{tabular}

Tabela 4. Wartości średnie i odchylenie standardowe dla poszczególnych skali i ich składowych wśród osób w różnym wieku

Źródło: badania własne

Badania dowiodły przy tym, że miejsce pochodzenia badanych nie różnicowało znacząco postawy patriotyzmu i tolerancji (zob. tabela 5).

\begin{tabular}{|c|c|c|c|c|c|c|c|c|c|}
\hline \multirow[b]{2}{*}{ SKALA } & \multirow[b]{2}{*}{ STWIERDZENIA } & \multicolumn{2}{|c|}{$\begin{array}{l}\text { Wieś, miasto } \\
\text { do } 50 \text { tys. }\end{array}$} & \multicolumn{2}{|c|}{$\begin{array}{c}\text { Miasto } \\
50-100 \text { tys. }\end{array}$} & \multicolumn{2}{|c|}{$\begin{array}{c}\text { Miasto } \\
\text { pow. } 50 \text { tys. }\end{array}$} & \multicolumn{2}{|c|}{ Test chi ${ }^{2}$} \\
\hline & & Średnia & SD & Średnia & SD & Średnia & SD & {$[\mathrm{r}]$} & {$[\mathrm{p}]$} \\
\hline \multirow{5}{*}{ 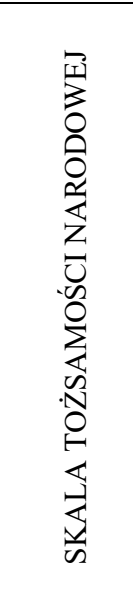 } & $\begin{array}{l}\text { Trzeba zawsze czcić naszą } \\
\text { narodową historię i dziedzictwo. }\end{array}$ & 4,78 & 0,46 & 4,62 & 0,76 & 4,80 & 0,44 & NS & 0,875 \\
\hline & $\begin{array}{l}\text { Mój kraj ma specjalną misję do } \\
\text { spełnienia w Europie dzięki } \\
\text { wartościom przez nas } \\
\text { wyznawanym. }\end{array}$ & 4,07 & 0,96 & 4,28 & 0,87 & 3,91 & 1,01 & NS & 0,537 \\
\hline & $\begin{array}{l}\text { Mój kraj powinien bardziej } \\
\text { stanowczo narzucać wartości } \\
\text { i zasady innym krajom, jeżeli te } \\
\text { wartości i zasady są dobre. }\end{array}$ & 3,71 & 1,19 & 3,82 & 0,95 & 4,00 & 0,89 & NS & 0,092 \\
\hline & $\begin{array}{l}\text { Mój kraj mógłby więcej } \\
\text { osiagnaćc, gdyby pozwolił na } \\
\text { większy wpływ z zagranicy. }\end{array}$ & 3,63 & 1,30 & 3,73 & 1,34 & 3,71 & 1,14 & NS & 0,638 \\
\hline & $\begin{array}{l}\text { Nie chciałbym mieszkać na stałe } \\
\text { w innym kraju niż Polska. }\end{array}$ & 4,09 & 1,13 & 3,45 & 1,20 & 4,02 & 1,23 & NS & 0,243 \\
\hline
\end{tabular}




\begin{tabular}{|c|c|c|c|c|c|c|c|c|c|}
\hline & $\begin{array}{l}\text { W czasie międzynarodowych } \\
\text { zawodów sportowych } \\
\text { przedstawiciele mojego kraju na } \\
\text { pewno przestrzegają zasad } \\
\text { fair play. }\end{array}$ & 4,32 & 0,77 & 4,19 & 0,74 & 3,98 & 1,05 & NS & 0,014 \\
\hline \multirow{6}{*}{ 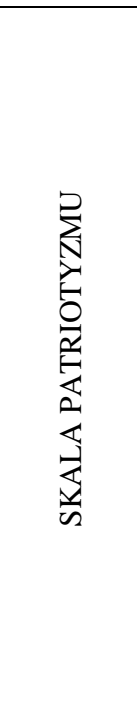 } & Kocham swój kraj. & 4,67 & 0,61 & 4,67 & 0,57 & 4,79 & 0,46 & NS & 0,291 \\
\hline & $\begin{array}{l}\text { Jestem dumny, że pochodzę ze } \\
\text { swojego kraju. }\end{array}$ & 4,73 & 0,55 & 4,56 & 0,64 & 4,86 & 0,44 & NS & 0,454 \\
\hline & $\begin{array}{l}\text { Jestem przywiązany do swojego } \\
\text { kraju i głęboko dotyka mnie } \\
\text { wszystko, co tyczy się mojego } \\
\text { kraju. }\end{array}$ & 4,38 & 0,88 & 3,94 & 0,87 & 4,52 & 0,66 & NS & 0,954 \\
\hline & $\begin{array}{l}\text { Chociaż nie zawsze zgadzam się } \\
\text { z działaniami rządu, czuję się } \\
\text { silnie przywiązany do swojego } \\
\text { kraju. }\end{array}$ & 4,33 & 0,82 & 3,77 & 1,01 & 4,48 & 0,71 & NS & 0,955 \\
\hline & $\begin{array}{l}\text { Trzeba zawsze służyć swojemu } \\
\text { krajowi. }\end{array}$ & 4,55 & 0,75 & 4,05 & 1,02 & 4,54 & 0,81 & NS & 0,333 \\
\hline & $\begin{array}{l}\text { Czuję się dumny, gdy sportowcy } \\
\text { z mojego kraju odnoszą sukcesy } \\
\text { na międzynarodowych } \\
\text { zawodach sportowych. }\end{array}$ & 4,79 & 0,48 & 4,76 & 0,59 & 4,82 & 0,43 & NS & 0,828 \\
\hline \multirow{3}{*}{ 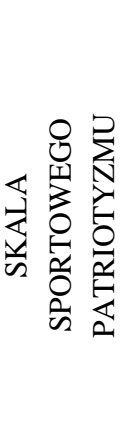 } & $\begin{array}{l}\text { Zawsze kibicuję Polsce na } \\
\text { międzynarodowych zawodach } \\
\text { sportowych (np. Igrzyska } \\
\text { Olimpijskie, Mundial itp.) }\end{array}$ & 4,70 & 0,54 & 4,51 & 0,64 & 4,59 & 0,76 & NS & 0,150 \\
\hline & $\begin{array}{l}\text { Zawsze kibicuję lepszej } \\
\text { drużynie, nawet jeżeli jej } \\
\text { przeciwnikiem jest Polska. }\end{array}$ & 2,57 & 1,59 & 2,71 & 1,54 & 2,68 & 1,43 & NS & 0,587 \\
\hline & $\begin{array}{l}\text { Czuję się dumny, kiedy mój kraj } \\
\text { wygrywa w międzynarodowych } \\
\text { zawodach sportowych. }\end{array}$ & 4,79 & 0,56 & 4,74 & 0,59 & 4,79 & 0,49 & NS & 0,847 \\
\hline \multirow{5}{*}{ 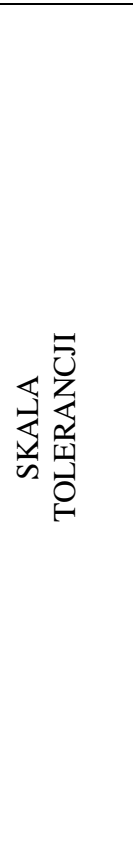 } & $\begin{array}{l}\text { Powinniśmy zezwalać na } \\
\text { osiedlanie się w Polsce osób } \\
\text { bliskich nam kulturowo, np. } \\
\text { z Ukrainy. }\end{array}$ & 3,28 & 1,17 & 3,44 & 1,11 & 3,14 & 1,26 & NS & 0,682 \\
\hline & $\begin{array}{l}\text { Powinniśmy zezwalać na } \\
\text { osiedlanie się w Polsce osób } \\
\text { o odmiennej kulturze, religii, np. } \\
\text { muzułmanów. }\end{array}$ & 2,86 & 1,27 & 3,40 & 1,50 & 2,48 & 1,41 & NS & 0,377 \\
\hline & $\begin{array}{l}\text { Powinniśmy zezwalać na } \\
\text { osiedlanie się w Polsce osób } \\
\text { z wysoko rozwiniętych krajów } \\
\text { z Europy, np. Francji. }\end{array}$ & 3,56 & 1,07 & 4,00 & 1,08 & 3,46 & 1,01 & NS & 0,879 \\
\hline & $\begin{array}{l}\text { Powinniśmy zezwalać na } \\
\text { osiedlanie się w Polsce osób } \\
\text { z biednych krajów z Europy, np. } \\
\text { z Mołdawii. }\end{array}$ & 3,24 & 1,12 & 3,79 & 1,19 & 3,05 & 1,15 & NS & 0,877 \\
\hline & $\begin{array}{l}\text { Zawsze staram się traktować } \\
\text { drugiego człowieka } \\
\text { szacunkiem, nawet jeżeli jego } \\
\text { poglądy i zwyczaje są odmienne } \\
\text { od moich. }\end{array}$ & 4,18 & 0,92 & 3,96 & 1,05 & 4,23 & 1,01 & NS & 0,940 \\
\hline
\end{tabular}

Tabela 5. Wartości średnie i odchylenie standardowe dla poszczególnych skali i ich składowych wśród osób pochodzących z miejscowości o różnej wielkości

Źródło: badania własne 
Zależności między skalami a zmiennymi niezależnymi (zob. tabela 6) pozwalają wnioskować, że:

- płeć istotnie różnicuje poziom sportowego patriotyzmu oraz tolerancji,

- wiek wpływa na postawę patriotyzmu i tożsamości narodowej we wszystkich skalach,

- miejsce pochodzenia nie różnicuje postawy patriotyzmu i tożsamości narodowej.

\begin{tabular}{|l|c|c|c|c|}
\hline Skale & Test $\chi^{2}$ & Płeć & Wiek & Miejsce pochodzenia \\
\hline \multirow{2}{*}{ Skala tożsamości narodowej } & {$[\mathrm{r}]$} & $\mathrm{NS}$ & $\mathbf{0 , 3 0 8 7}$ & NS \\
\cline { 2 - 5 } & {$[\mathrm{p}]$} & 0,093 & $\mathbf{0 , 0 0 0}$ & 0,641 \\
\hline \multirow{2}{*}{ Skala patriotyzmu } & {$[\mathrm{r}]$} & $\mathrm{NS}$ & $\mathbf{0 , 1 3 3 6}$ & NS \\
\cline { 2 - 5 } Skala sportowego patriotyzmu & {$[\mathrm{p}]$} & 0,076 & $\mathbf{0 , 0 3 3}$ & 0,932 \\
\hline \multirow{3}{*}{ Skala tolerancji } & {$[\mathrm{r}]$} & $\mathbf{0 , 2 2 6 7}$ & $\mathbf{0 , 3 1 2 3}$ & NS \\
\cline { 2 - 5 } & {$[\mathrm{p}]$} & $\mathbf{0 , 0 0 0}$ & $\mathbf{0 , 0 0 0}$ & 0,916 \\
\hline
\end{tabular}

Tabela 6. Zależności pomiędzy skalami

Źródło: badania własne

\section{WNIOSKI I REKOMENDACJE}

Celem przeprowadzonych badań empirycznych było wskazanie zależności między następującymi wartościami: tożsamością narodową, patriotyzmem, tolerancją i sportowym patriotyzmem. Badania miały więc charakter nomotetyczny. Analiza uzyskanych danych wskazuje na bardzo silne poczucie patriotyzmu, tożsamości narodowej i patriotyzmu sportowego. Badani wysoko cenią sobie tolerancję, zgodnie twierdząc, że kierują się szacunkiem dla drugiego człowieka. Badani najbardziej przychylnie opowiadali się za przyjmowaniem imigrantów z wysoko rozwiniętych krajów Europy (średnia 3,75; SD=1,08), przejawiali natomiast nieprzychylny stosunek do osób o odmiennej kulturze i religii, np. muzułmanów (średnia 2,94; $\mathrm{SD}=1,41$ ).

Badaniu poddano również związki tożsamości narodowej z przyjętymi zmiennymi, co wskazało na wysoką korelację skali tożsamości narodowej, sportowego patriotyzmu oraz tolerancji. Skala patriotyczna znacząco wpływała na wyniki skali tożsamości narodowej i sportowego patriotyzmu, nie różnicowała natomiast postawy tolerancji. Skala tolerancji istotnie korelowała ze skalą patriotyzmu, sportowego patriotyzmu, tożsamości narodowej.

Wiek i płeć wyraźnie korelowały z wartościami tożsamości narodowej, miejsce zamieszkania natomiast nie wpływało na wyniki badań. Mężczyźni charakteryzowali się znacząco wyższym poziomem poczucia patriotyzmu w zakresie miłości i dumy z Ojczyzny, chociaż nie zawsze zgadzają się z działaniami rządu. W zakresie tożsamości narodowej potwierdzili szacunek do historii i dziedzictwa narodowego oraz przypisywali Polsce specjalną misję w Europie. W sportowej rywalizacji częściej stoją po stronie „naszych” nawet z perspektywą przegranej. Kobiety wykazały się znacząco wyższym poziomem tolerancji 
i akceptacji wobec innych narodów i kultur, częściej przyjmując postawę otwartości na osiedlanie się w Polsce osób innych narodowości bez względy na pochodzenie i przyczynę.

Młodzież licealna częściej niż młodzi dorośli potwierdzała swoją miłość do Ojczyzny, przypisując jej misję w Europie, optując za narzuceniem naszych wartości i zasad narodowych innym krajom, co pozwoli na osiągnięcie sukcesu na scenie międzynarodowej. W sportowej rywalizacji częściej stoją po stronie ,naszych” nawet z perspektywą przegranej. Jednoczenie badani pomiędzy 16 a 18 rokiem życia wykazali się znacząco wyższym poziomem tolerancji i akceptacji wobec innych narodów i kultur, częściej przyjmując postawę otwartości na osiedlanie się w Polsce osób innych narodowości bez względu na pochodzenie i przyczynę.

Wyniki badań wskazują na istnienie korelacji między skalami tożsamości narodowej, patriotyzmu, sportowego patriotyzmu i tolerancji, co postulowała przyjęta hipoteza $\left(\mathrm{H}_{1}\right)$, jednakże skala patriotyzmu nie różnicowała postawy tolerancji. Stwierdzono też, że wiek i płeć powiązane są z silnymi postawami patriotycznymi, tolerancji i tożsamości narodowej, miejsce zamieszkania natomiast nie różnicuje tych postaw. Można więc wskazać, że ta hipoteza, choć nie w całości, została zweryfikowana negatywnie.

Tożsamość narodowa zarówno jako element tożsamości społecznej, jak i indywidualnej wpływa na system wartości, a tym samym dokonywane wybory, pobudzające człowieka do podejmowania przedsięwzięć życiowych i budowania na ich podstawie sensu życia. Dlatego też w procesach wychowania i kształcenia na każdym etapie edukacyjnym tym baczniej warto byłoby zwrócić uwagę na internalizację u wychowanków wartości utrwalonych w kulturze danego narodu. Przy czym współcześnie, w wielonarodowościowej Europie i coraz bardziej kulturowo zróżnicowanej Polsce kwestia ta nabiera szczególnego znaczenia.

To tożsamość narodowa warunkuje egzystowanie jednostki w społeczeństwie, sprzyja działaniu na rzecz dobra wspólnego, tworzeniu społeczeństwa obywatelskiego czy po prostu świadomości siebie i kategorii pozwalających identyfikować innych jako „swoich”. Wpływy kształcenia i wychowania są tutaj niezastąpione - winny tym bardziej sprzyjać rozwojowi uczniów, aby stawali się oni twórczymi uczestnikami wspólnoty społecznej, kulturowej, narodowej i globalnej, a jednocześnie, aby byli zdolni do samorealizacji, zachowania odrębności i tworzenia tożsamości indywidualnej, która nie będzie w sprzeczności z tożsamością narodową. Oprócz treści przedmiotowych „nasyconych” wartościami i narodowymi, i ogólnoludzkimi, warto ideały te egzemplifikować we wszystkich interakcjach społecznych, a przekazywać je również podczas zabawy i rywalizacji sportowej, które - jak dowodzą analizy wyników badań - sprzyjają tolerancji.

Problematyka podjętych badań dotyczących tożsamości narodowej, patriotyzmu i tolerancji koreluje $\mathrm{z}$ wagą tego tematu w kontekście nauk o bezpieczeństwie. Jak wskazuje Strategia Bezpieczeństwa Narodowego Rzeczypospolitej Polskiej, ochrona i umacnianie tożsamości narodowej stanowi ważne zadanie państwa. Cele te można osiągnąć poprzez pielęgnowanie 
kultury narodowej, ochronę dziedzictwa kulturowego, aktywizację kapitału społecznego oraz wzmacnianie postaw patriotycznych ${ }^{69}$.

Istnieje zatem potrzeba przygotowania i prowadzenia systematycznych badań dotyczących budowy bezpieczeństwa narodowego w takich wymiarach jak tożsamość narodowa, patriotyzm, tolerancja i sport. Słuszne wydaje się zatem prowadzenie dalszych badań, których wyniki mogą posłużyć wskazaniu implikacji do praktycznego zastosowania wedukacji przedszkolnej, podstawowej, średniej i akademickiej.

\section{BIBLIOGRAFIA}

Andrejuk Katarzyna. 2015. "Postawy Wobec Imigrantów w Świetle Wyników Europejskiego Sondażu Społecznego 2014-2015. Polska Na Tle Europy.” Warszawa. https://depot.ceon.pl/handle/123456789/12510.

Bairner Alan. 2001. Sport, Nationalism, and Globalization: European and North American Perspectives. New York: State University of New York Press.

Bańko Mirosław. 2000. Inny Słownik Języka Polskiego PWN, t. 2. Warszawa: PWN, 2000.

Bartyzel Jacek, Bogdan Szlachta, Adam Wielomski. 2007. Encyklopedia Polityczna, Tom 1. Radom: Wydawnictwo Polwen.

Berger, Peter L., and Thomas Luckmann. 1966. The Social Construction of Reality: A Treatise in the Sociology of Knowledge. New York: Doubleday.

Berggren, Niclas, and Therese Nilsson. 2015. "Globalization and the Transmission of Social Values: The Case of Tolerance." Journal of Comparative Economics 43, no. 2 : 371-89. https://doi.org/10.1016/J.JCE.2015.02.005.

Berggren Niclas, and Therese Nilsson. 2016. "Tolerance in the United States: Does Economic Freedom Transform Racial, Religious, Political and Sexual Attitudes?" European Journal of Political Economy 45 (December): 53-70. https://doi.org/10.1016/j.ejpoleco.2016.06.001.

Berry John W. 2001. “A Psychology of Immigration.” Journal of Social Issues 57, no. 3: 615-31.

Billings Andrew C., Kenon A. Brown, and Natalie A. Brown. 2013. "5,535 Hours of Impact: Effects of Olympic Media on Nationalism Attitudes.: E-Zasoby Dostępne w Bibliotece Głównej ASW." Journal of Broadcasting \& Electronic Media 57, no. 4: 579-95. https://doi.org/DOI: 10.1080/08838151.2013.850591.

Błeszyńska K. 2002. “Tożsamość Polaków w Dobie Globalnej.” In Edukacja Wobec Ładu Globalnego, edited by T. Lewowicki. Warszawa: Wyd. Akademickie „Żak”.

Bogardus Emory S. 1958. "Racial Distance Changes in the United States during the Past 30 Years. - PsycNET." Sociology \& Social Research 43: 127-34. https://psycnet.apa.org/ record/1960-01208-001.

Bogardus Emory S. 1925. "Social Distance and Its Origins." Sociology \& Social Research 9 : 216-25.

Bokova I. 2016. “Sport Na Rzecz Rozwoju i Pokoju,” W http://www.un.org.pl/sport-na-rzeczrozwoju-i-pokoju.

Burgoński Piotr. 2010. "Polski Patriotyzm w Dobie Komunizmu. Koncepcja Patriotyzmu w Nauczaniu Księdza Jerzego Popiełuszki.” Warszawskie Studia Teologiczne 23, no. 1.

\footnotetext{
${ }^{69}$ Strategia Bezpieczeństwa Narodowego Rzeczypospolitej Polskiej, 2014, https://www.bbn.gov.pl/ftp/SBN RP.pdf.
} 
https://depot.ceon.pl/handle/123456789/7080.

Butterworth Michael L. 2007. "The Politics of the Pitch: Claiming and Contesting Democracy Through the Iraqi National Soccer Team." Communication and Critical/Cultural Studies 4, no. 2 (June): 184-203. https://doi.org/10.1080/14791420701296554.

Buzan Barry, Ole Wæver, and Jaap de. Wilde. 1998. Security: A New Framework for Analysis. Boulder, Colorado: Lynne Rienner Pub.

Cedro Patrycja. 2013. "Społeczna Rola Sportu." Rozprawy Społeczne 7, no. 2: 77-86. http://www.fiba.com/pages/eng/fc/FIBA/.

Chouliaraki Lilie, Myria Georgiou, and Rafal Zaborowski. 2017. "The European \&quot;Migration Crisis\&quot; and the Media A Cross-European Press Content Analysis," In https://s3.amazonaws.com/academia.edu.documents/53658010/Migration_and_media_repor t_FINAL.pdf?AWSAccessKeyId=AKIAIWOWYYGZ2Y53UL3A\&Expires=1555684741

$\&$ Signature=rel574SoaoreHAcNHUn8Ihz6fZY\%3D\&response-content-

disposition=inline\%3B filename\%3DThe_European_.

Domalewska Dorota. 2016. "Immigration, Stereotypes, and Social Security: The Portrayal of Migrant Groups in Public Discourse." Security and Defence Quarterly 4, no. 13: 15-31. https://doi.org/https://doi.org/10.35467/sdq/103231.

Domalewska Dorota, Żakowska Marzena. 2019. "Migracje z Państw Objętych Konfliktami Zbrojnymi - Analiza Wypowiedzi Parlamentarzystów Na Twitterze.” Przegląd Europejski 2.

Drabarek Anna. 2016. "Kontrowersje Wokół Pojęcia Patriotyzmu." In Klasy Mundurowe. Od Teorii Do Dobrych Praktyk, edited by A. Skrabacz, L. Kanarski, and L. Urych. Warszawa: Wydawnictwo Akademii Obrony Narodowej.

Erikson Erik H. (Erik Homburger). 1994. Identity: Youth and Crisis. W. W. Norton.

Gajda Stanisław. 2007. "Tożsamość a Język.” w: Człowiek Wobec Wyzwań Współczesności.

Upadek Wartości Czy Walka o Wartość?, re. J. Mazur, A. Małyska, K. Sobstyl. Lublin: Wydawnictwo UMCS.

Gawlik-Kobylińska Małgorzata. 2018. "Ethics and Innovations in Military Environments." Zeszyty Naukowe Politechniki Śląskiej 128: 89-97.

Glombik Konrad. 2013. “Tolerancja Jako Postawa Moralna.” Studia Oecumenica: 113-26.

Goffman Erving. 2008. Człowiek w Teatrze Życia Codziennego. Warszawa: Wydawnictwo Aletheia.

Golka Marian. 2010. Imiona Wielokulturowości. Warszawa: Warszawskie Wydawn. Literackie Muza SA.

Górnikiewicz Marcin, Szczurek Tadeusz.2017. "Determinanty Kształtowania Bezpieczeństwa Wewnętrznego." w: Prognozowanie Międzynarodowych Stosunków Wojskowych Na Podstawie Uwarunkowań Społeczno-Kulturowych, red. Edyta. Ślachcińska, 103-13. Poznań: Wydawnictwo Wyższej Szkoły Bankowej.

Grzymała-Moszczyńska Halina. 2000. Uchodźcy. Podręcznik Dla Osób Pracujących z Uchodźcami. Kraków: Nomos.

Hatton Timothy J. 2016. "Public Opinion on Immigration: Has the Recession Changed Minds?" Economic Policy 86 : 205-46.

Huntington Samuel P. 2011. The Clash of Civilizations and the Remaking of World Order. New York: Simon \& Schuster.

Ivancik Radoslav, Jurcak Vojtech, and Necas Pavel. 2014. "On Some Contemporary Global 
Security Risks and Challenges." Security and Defence Quarterly 4, no. 3 (September 30): 34-49. https://doi.org/10.5604/23008741.1152548.

Jura J., and Kałużyńska K. 2015. "Obraz Obcokrajowców i Imigrantów w Polskich Mediach Tradycyjnych i Internetowych.” In Imigranci o Wysokich Kwalifikacjach Na Polskim Rynku Pracy., edited by J. Konieczna-Sałamatin. Warszawa.

Kaczorowski Ryszard. 2004. Wielka Encyklopedia PWN. Warszawa: PWN.

Kaldor Mary. 2013. "In Defence of New Wars.” Stability: International Journal of Security and

Development 2, no. 1 (March 7): 4. https://doi.org/http://doi.org/10.5334/sta.at.

Kłoskowska Antonina. 1996. Kultury Narodowe u Korzeni. Warszawa: Wyd. Oficyna Naukowa.

Knapik W. 2011. "Tradycje Jako Element Tożsamości Kulturowej Wiejskich Społeczności

Lokalnych.” In Tradycja Dla Współczesności. Ciągłość i Zmiana, t. 3, red. J. Styka and M.

Dziekanowska. Lublin: Wydawnictwo UMCS.

Kopaliński Władysław. 2000. Słownik Wyrazów Obcych i Zwrotów Obcojęzycznych z Almamanachem. Warszawa: Świat Książki.

Kunikowski Jerzy. 2012. "Istota Patriotyzmu." In Patriotyzm Współczesnych Polaków, red. A. Skrabacz. Warszawa: Centralna Biblioteka Wojskowa im. Marszałka Józefa Piłsudskiego.

Lazari-Pawłowska Ija. 1984. “Trzy Pojęcia Tolerancji.” Studia Filozoficzne 8: 105.

Marino Sara, Dawes Simon. 2016. "Introduction to Fortress Europe: Media, Migration and Borders." Networking Knowledge 9, no. 4: 1-6. http://eprints.bournemouth.ac.uk/ 29782/1/Editorial Fortress Europe.pdf.

Martin Denis-Constant. 1995. "The Choices of Identity." Social Identities 1, no. 1 (February 23): 5-20. https://doi.org/10.1080/13504630.1995.9959423.

Mitręga Adrian, Kozub Marian. 2019. "The Influence of Strategic Culture on Shaping Security Policy." Security and Defence Quarterly 27, no. 5 (December 24): 44-56. https://doi.org/10.35467/sdq/111661.

Panfil Łukasz, Seweryniak Tomasz. 2009. Wybrane Czynniki Umiędzynaradawiania Kadr Organizacji Sportowych. Wrocław: AWF.

Parsons Talcott. 1967. Sociological Theory and Modern Society. New York: Free Press,.

Pisarek Mateusz. 2015. "Wydarzenia Sportowe i Sukcesy Polskich Sportowców Zachętą Do Budowania Tożsamości Narodowej Oraz Postaw Patriotycznych.” Studia Leopoliensia 8 : 457-67. http://www.szyran.republika.pl/artykuly/patriotyzm.htm.

Saleh Alam. 2010. "Broadening the Concept of Security: Identity and Societal Security." Geopolitics Quarterly 6, no. 4: 228-41.

Sidis Boris. 1905. Multiple Personality: An Experimental Investigation into the Nature of Human Individuality. New York.

Strategia Bezpieczeństwa Narodowego Rzeczypospolitej Polskiej, 2014. https://www.bbn.gov.pl/ ftp/SBN RP.pdf.

Strauss Anselm L. 1959. Mirrors \&amp; Masks: The Search for Identity. Glenoce: Free Press.

Stróżewski Władysław. 2013. Logos, Wartość, Miłość. Kraków: Znak.

Sułek Andrzej. 2012. Psychospołeczne Uwarunkowania Patriotyzmu i Nacjonalizmu. Kraków: Uniwersytet Papieski Jana Pawła II.

Świerszcz K. 2016. "Integralne Wychowanie Na Rzecz Integralnego Bezpieczeństwa - Jako Naglące Wyzwanie Współczesnych Czasów.” In Obronność Państwa. Uwarunkowania Oraz 
Organizacja Bezpieczeństwa i Obronności, edited by Z. Trejnis and M. Marciniak, 158-93. Toruń: Adam Marszałek.

Szacki Jerzy. 2013. "Patriotyzm Jako Błąd i Jako Cnota.” Gazeta Wyborcza.

Tajfel H. 1978. "The Structure of Our Views about Society." In Introducing Social Psychology, edited by H. Tajfel and C. Fraser. Harmondsworth: Penguin Books.

Tajfel H. 1982. "Social Psychology of Intergroup Relations.” Annual Review of Psychology 33, no. 1 (January 28): 1-39. https://doi.org/10.1146/annurev.ps.33.020182.000245.

Tajfel H, Turner JC, 1979. ... WG Austin - Organizational identity: A, and undefined 1979. "An Integrative Theory of Intergroup Conflict." The Social Psychology of Intergroup Relations 33, no. 47.

Tausk Victor, Roazen Paul. 2017. Sexuality, War, and Schizophrenia: Collected Psychoanalytic Papers. New Jersey: Routledge.

Urych Ilona. 2018. "Military Classes as an Area of Interest for the Armed Forces of the Republic of Poland. Experience and Perspectives.” Defense Resources Management 17, no. 2.

Urych Ilona. 2017. "Od Kultury Fizycznej Do Patriotyzmu i Od Patriotyzmu Do Kultury Fizycznej. O Kształtowaniu Postaw w Tworzeniu Bezpieczeństwa Narodowego.” w: Powrót Do Ojczyzny? Patriotyzm Wobec Nowych Czasów. Kontynuacje i Poszukiwania, edited by C. Smuniewski and P. Sporek. Warszawa: Instytut Nauk o Polityce.

Waever Ole. 2008. "The Changing Agenda of Societal Security." In Globalization and Environmental Challenges, Reconceptualizing Security in the 21 st Century, ed. by H. G. et al. Brauch. Berlin: Springer.

Wong Stan Hok Wui, Chen Lee Kuan, Ho Karl, and Clarke Harold D. 2019. "Immigrant Influx and Generational Politics: A Comparative Case Study of Hong Kong and Taiwan.” Electoral Studies 58 (April 1): 84-93. https://doi.org/10.1016/j.electstud.2018.12.008.

Żakowska, M., Domalewska D. 2019. 'Factors Determining Polish Parliamentarians' Tweets on Migration: A Case Study of Poland.” Politologicky Casopis 2019, no. 3. https://doi.org/10.5817/PC2019-3-200.

Żaryn Jan. 2019. "Prof. Żaryn w Miesięczniku \&quot;WSieci Historii\&quot;: \&quot;Sport Ma w Sobie Siłę, w Której Mieszczą Się Trzy Wielkie Wartości: Prawość, Wolność i Patriotyzm\&quot;" WPolityce.Pl. Accessed June 30. https://wpolityce.pl/polityka/184107prof-zaryn-w-miesieczniku-wsieci-historii-sport-ma-w-sobie-sile-w-ktorej-mieszcza-sietrzy-wielkie-wartosci-prawosc-wolnosc-i-patriotyzm.

Zielińska Maria, Szaban Dorota. 2017. "Od Tolerancji Nowoczesnej Do Ponowoczesnej. Dynamika i Uwarunkowania Postaw Wobec Imigrantów i Mniejszości Narodowych Wśród Mieszkańców Województwa Lubuskiego w Latach 2005-2014." Studia Humanistyczne AGH 16, no. 1 (June 16): 7-21. https://doi.org/10.7494/human.2017.16.1.7-21. 